\title{
Alpana Roy*
}

\section{POSTCOLONIAL THEORY AND LAW: A CRITICAL INTRODUCTION}

\begin{abstract}
The purpose of this article is to encourage legal scholars to engage more actively with postcolonial discourse. To this end, the article will outline key concepts in postcolonial theory - such as colonialism, imperialism, decolonisation and neo-colonialism, and will also trace the work of major theorists in this area - Frantz Fanon, Homi Bhabha, Gayatri Spivak, and Edward Said. As this article presents itself as a contribution to the study of postcolonial theory and the law, it will focus on contemporary developments in Australian law reform. Specifically, the article will discuss the Law Reform Commission of Western Australia's Final Report on Aboriginal Customary Laws.
\end{abstract}

\section{INTRODUCTION}

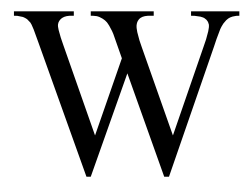

hile conversations between law and postcolonialism have been 'infrequent' ${ }^{1}$ and remain largely unmapped, postcolonial discourse is now the major methodological tool with which to trace the patterns of epistemological and pedagogic reterritorialisation of the non-Western world. With respect to legal discourse, Peter Fitzpatrick and Eve Darian-Smith suggest that "postcolonialism is now the main mode in which the West's relation to its "other" is critically explored, and law has been...[in] the forefront of that very relation'. ${ }^{2}$ Nevertheless, while postcolonial theory's status as a discipline may arguably be more established in other academic areas, it is increasingly being recognised by legal scholars as a methodological tool with which to scrutinise the nature of legal discourse. ${ }^{3}$

* Lecturer, Faculty of Law, University of Technology, Sydney. I would like to note my sincere thanks to Jenni Millbank for all of her constructive comments on various drafts of this article.

1 Peter Fitzpatrick and Eve Darian-Smith, 'Laws of the Postcolonial: an Insistent Introduction' in Fitzpatrick and Darian-Smith (eds), Laws of the Postcolonial (1999) $1-15,4$.

2 Ibid. Please note that the concept of the 'Other' will be discussed in further detail below.

3 For example, while the first edition of Margaret Davies' excellent introductory text on jurisprudence Asking the Law Question (1994) did not focus specifically on postcolonial theory, the second edition (2002) includes a separate chapter on the discourses of critical race and postcolonial theory: See 'Race and Colonialism: Legal 
In this postmodern era, it seems hardly controversial to promote an interdisciplinary approach to law. As Davies suggests, 'the landscape of legal theory is now amazingly diverse'. Indeed, legal theory today admits to using a wide range of discourses including (but certainly not limited to) feminist theory, literary criticism, economics, psychoanalysis, philosophy, queer theory, political theory, and more recently, postcolonial and race theory. Contemporary legal theory is therefore not only rapidly evolving, but unavoidably plural.

The purpose of this article is to encourage legal scholars to engage more actively with postcolonial discourse as its critical methodology provides an innovative way of thinking about the existing structures of law. It will be argued that, as conscious interactions between law and postcolonialism remain limited (or largely unremarked), it is even more important to further this field of critical endeavour. Indeed, a postcolonial analysis of law provokes a different reading of it, and this in turn instigates a more contextual and expanded understanding of the concept of law. This is important, as the law has in many ways essentially remained a 'Eurocentric enterprise'. 5 To this end, the discussion below will outline key concepts in postcolonial theory, and will also trace postcolonial theory's relationship with the law — with a particular focus on contemporary developments in Australian law reform. This article, then, presents itself as a contribution to the study of postcolonial theory and the law.

\section{Postcolonial Theory: AN OVERVIEW}

The heterogeneity of the colonial project has resulted in many legacies. One of these has been the emergence of postcolonial thought as a distinct, critical, theoretical perspective.

The term 'postcolonial' encompasses a diverse range of ideas, theories, and indeed, theorists. Postcolonial discourse as a 'theory' is interdisciplinary and hybrid, in its writing and its effects. The polymorphous character of postcolonial theory, its plural genealogies, and its vast vocabulary has meant that there is little agreement among postcolonial scholars as to the precise nature and scope of the discourse. It is by no means a homogenous, unitary theory. ${ }^{6}$ As there is considerable dispute

Theory as "White Mythology" in Margaret Davies, Asking the Law Question: the Dissolution of Legal Theory (2nd ed Lawbook Co, Sydney, 2002) 257-94.

Ibid v.

See Kenneth B Nunn, 'Law as a Eurocentric Enterprise' (1997) 15 Law and Inequality 323.

6 Indeed, in the narrow construction of the term, postcolonial theory cannot even be classified as a 'theory'. For example, postcolonial theory is unlikely to satisfy Foucault's definition of a theory 'in the strict sense of the term: the deduction, on the basis of a number of axioms, of an abstract model applicable to an indefinite number 
regarding the precise definition and meaning of the term 'postcolonialism', the term itself has been the subject of prolonged discussion. ${ }^{7}$

The term was first used in the years following the Second World War, when decolonisation resulted in the emergence of newly independent nation-states. The term has now expanded well beyond this original meaning, and is now used to include all aspects of the heterogeneous colonial process, from the beginning of colonial contact to the present day. The term has also been closely associated with postmodernism, and has been used to mean a nebulous range of discursive practices, such as: slavery, dispossession, settlement, migration, multiculturalism, suppression, resistance, representation, difference, race, gender and sexuality, class, otherness, place, diaspora, nomadism, hybridity, indigeneity, ethnicity and identity. ${ }^{8}$ Indeed, Bill Ashcroft, Gareth Griffiths and Helen Tiffin, suggest that the propensity towards applying the term 'postcolonial' 'to any kind of marginality' runs the risk of losing its meaning altogether. ${ }^{9}$

The use of the term 'postcolonial' became popular in the 1980s, and was used to identify societies and cultures where colonial rule had formally ended, such as countries in Asia, Africa, South America, and the Caribbean. ${ }^{10}$ However, while colonial rule has ended - at least legally — in most of the previously colonised nations, the former colonised world has not been fully 'decolonised'. As Robert Young, one of the foremost critics in postcolonial theory points out, the list of colonies, overseas departments, unincorporated territories (and other forms of colonial descriptors) are still surprisingly long. ${ }^{11}$ Significantly, the Indigenous

of empirical descriptions': See Michel Foucault, The Archaeology of Knowledge and the Discourse on Language (1972) 114. Young suggests that this is because postcolonial theory has developed a range of 'conceptual resources', with no single methodology. Moreover, postcolonial theory draws on a vast (and often contested) range of theories and practices in order to develop its own epistemology: See Robert JC Young, Postcolonialism: an Historical Introduction (2001) 64.

7 There is even disagreement as to whether the term is hyphenated or not, ie whether the term is 'post-colonial' or 'postcolonial'. Leela Gandhi suggests that some critics use the hyphenated form 'post-colonial' as a 'decisive temporal marker of the decolonising process'. While others use the non-hyphenated form 'postcolonial' to emphasise the long history of the effects of colonialism, and the lack of chronological separation between colonialism and its aftermath: See Leela Gandhi, Postcolonial Theory: a Critical Introduction (1998) 3.

8 For an excellent discussion of postmodernism and legal theory, see Davies, above $\mathrm{n}$ 3, 295-351.

9 Bill Ashcroft, Gareth Griffiths and Helen Tiffin (eds), The Post-Colonial Studies Reader (1995) 2.

$10 \quad$ Davies, above n 3, 278.

11 For example, British Gibraltar, the Falklands/Malvinas, and other islands; Danish Greenland; Dutch Antilles; French Guiana, Martinique, Reunion, St Pierre and Miquelon; Spanish Ceuta, Melilla, and Canary Islands; US Puerto Rico, Samoa, and the Virgin Islands. Moreover, several Pacific islands remain colonies of the US and 
inhabitants in former colonies such as Australia, New Zealand, Canada, and the United States remain arguably 'colonised'. ${ }^{12}$ Several prominent postcolonial theorists, such as Gayatri Spivak and Edward Said, have also argued that colonialism does not really end, except in a legal sense, as the effects of colonisation are enduring for both the colonisers and the colonised. ${ }^{13}$

While the colonial era typically implied a relatively clear demarcation between the colonisers and the colonised, postcolonialism refers to a more discursive condition, where the discourse and culture of the former imperial power has left an undeniable scar on the psyche of the colonised. ${ }^{14}$ In the words of Gyan Prakash:

The postcolonial exists as an aftermath, as an after - after being worked over by colonialism. Criticism formed in this process of the enunciation of discourses of domination occupies a space that is neither inside nor outside the history of western domination but in a tangential relation to it. This is what Homi Bhabha calls an in-between, hybrid position of practice and negotiation, or what Gayatri Chakravorty Spivak terms catachresis; 'reversing, displacing, and seizing the apparatus of value-coding, ${ }^{15}$

Significantly, Margaret Davies also points out that the term 'postcolonial' recognises that

decolonisation does not result in a return to a pre-colonial state, but rather movement into a 'postcolonial' state, where the effects of colonialism have become an inextricable part of the culture and of its legal, educational, and political institutions, and where the colonial state still serves as a reference point in local discourse. ${ }^{16}$

Given the nature of its inquiry, postcolonial theory, clearly, does not inhabit an atemporal space. Indeed, the discourse (even by name) is inextricably tied to both

France. There also continues to be independence struggles in this postcolonial era for more recently occupied territories. For example, Tibet by China; Palestine and the West Bank by Israel; and Northern Ireland by the United Kingdom: See Young, above $n$ 6, 3-4.

This is certainly the view of Indigenous scholar, Irene Watson, with respect to Australian Aboriginal people: See Irene Watson, 'Indigenous Peoples' Law-Ways: Survival Against the Colonial State' (1997) 8 Australian Feminist Law Journal 39. Both Spivak and Said's work will be discussed in further detail below. For example, well before the emergence of postcolonial theory, theorists such as Frantz Fanon wrote of the double consciousness experience of the colonised person; ie the racially oppressed person continues to operate in their own culture, while at the same time are forced to process the image of themselves constructed by the dominant group. See Frantz Fanon, Black Skin, White Masks (1967). Social Text 8, 8 . 
temporal and spatial global processes. However, while it is important to be aware of postcolonial theory's temporal and contextual space (to be discussed in further detail below), its strength lies not in its historical foundations, but in its enormous potential as a set of theoretical and methodological tools for deconstructing the colonial foundations of contemporary power structures — including legal ones.

\section{POSTCOLONIAL THEORY AND LAW: A CRITICAL RELATION?}

Before proceeding to discuss postcolonial theory as discourse, it is important, at least briefly, to locate law's relation to this critical methodology. Although it is a difficult task to define the precise space in which postcolonial theory exists in relation to the law, it is fairly safe to assume that the relationship is a critical one. As Fitzpatrick and Darian-Smith suggest, 'postcolonialism would ... oppose those who perceived law as a great civilizing mode of colonization or as an instrument of development or of modernization. ${ }^{17}$ Postcolonial legal theorists — that is, legal theorists who have engaged in postcolonial theory - have focused on the role played by law during the colonial process. These theorists have traced the ways in which colonial laws - as products of the colonising power, were imposed upon the vast territories of the annexed cultures. Significantly, however, as postcolonial theory's primary concern is with the present, these theorists have also endeavoured to show that the ideological effects of colonial laws continue to have contemporary relevance as they continue to be used as an instrument of control in this postcolonial world.

The critical space inhabited by postcolonial legal theorists in their relationship with the law usually begins at a familiar place - the critique of liberal positivism. While it is unnecessary to go into the details of liberal positivism as a system of political philosophy here, it is sufficient for our purposes to note that this intellectual tradition has dominated legal reasoning since the $20^{\text {th }}$ century. ${ }^{18}$ Legal scholars who have engaged with postcolonial theory, such as Peter Fitzpatrick and Margaret Davies suggest, that while liberal positivism creates the theoretical forum for legal neutrality, formal equality and legal objectivity, its unwillingness to see from Other positions essentially results in the promotion of substantive inequality. ${ }^{19}$ In the eloquent words of Roberto Unger, the neutrality of law is 'falsified by the reality of life in liberal society. ${ }^{20}$ Davies also suggests that the Western legal project, framed in its liberal positivist tradition, has generally excluded (or not recognised) other

Fitzpatrick and Darian-Smith, above n 1.

It should be noted that 'liberalism' and 'positivism' are distinct philosophical concepts. For a useful discussion of liberalism within the context of legal theory, see Stephen Bottomley and Simon Bronitt, Law in Context (3rd ed, 2006) 16-58. For positivism, see Davies, above n 3, 90-104.

See Peter Fitzpatrick, The Mythology of Modern Law (1992); Fitzpatrick and DarianSmith, above $\mathrm{n} 1$.

Roberto M Unger, Law in Modern Society: Toward a Criticism of Social Theory (1976) 181. 
forms of law. According to Davies, this partial, subjective, and ethnocentric law excludes

\begin{abstract}
the possibility of law existing outside its domain yet within its 'own' territory; it excludes questions about its own existence, presuming instead its own legitimacy, even though this legitimacy is arguably due to nothing more than force (and in the case of many colonised nations, is completely dubious); and it excludes from the idea or concept of law any law which is not institutionalised after a Western model. ${ }^{21}$
\end{abstract}

The critique of liberal positivism by postcolonial legal scholars place these theorists within the vast domain of critical legal studies. In broad terms, 'critical legal studies' refers to the critical modern and postmodern discourses which have emerged in Western legal systems in the last two decades. ${ }^{22}$ These include (but are not limited to) various fields of scholarship, such as postmodernism, deconstruction, postcolonial theory, feminist legal theory, critical race theory, and queer theory. Given the range and diversity of these critical perspectives, it is impossible to define 'critical legal studies' in its broad sense. However, a common theme running through these critical perspectives include a rejection of liberal legalism, legal objectivity and neutrality, and an ideological commitment to a contextual analysis of the law. ${ }^{23}$ At its core, the scholarship of critical legal studies has challenged the static monolithic categories constructed by liberal positivist law, and in doing so have insisted upon the necessity of recognising partial realities, subjugated knowledges, and subaltern positions.

Due to the nature of its inquiry, postcolonial theory - like other critical modern and postmodern methodologies - is useful, as the discourse offers a very different reading of the law (and of the world generally). Indeed, given the history of Western legal discourse, this is clearly important. As will be discussed in further detail below, postcolonial theory challenges the view of Otherness proffered by Western culture, and focuses on identities which have been constructed independently from the dominant narrative. Indeed, this issue of identity is fundamental, as the historically marginalised insist upon the recognition of their own construction in this postcolonial world. While postcolonial theory is critical of the colonial and imperial projects, and the continuing hegemonic position of Western economies and cultures, it actively engages in the formation of positive new political identities. ${ }^{24}$ In this way, postcolonial discourse is both theoretical and interventionist in its critique of contemporary forms of power. Significantly, a

21

Davies, above n 3, 277.

The term 'Critical Legal Studies' (CLS) also refers to the distinct political movement which emerged in the legal academy in the late 1970s. For an excellent discussion of Critical Legal Studies, see Davies, above n 3, 167-195.

Ibid. See especially 167-69, 257.

In contrast, the terms 'colonialism', 'imperialism', and 'neocolonialism' generally only operate in a negative relation to their source epistemologies. 
postcolonial view not only queries the base from which liberal positivist law unthinkingly functions; it also provides a different forum in which the law's taxonomic structures and ontological foundations may be understood from the Other's perspective.

\section{The Location of Postcolonial Theory and Law as Discourse(S)}

At least for the purposes of postcolonial theory, the history of colonialism began symbolically in 1492. Although the lineage of postcolonial theory is historically complex, as a discourse postcolonial theory essentially revisits the narrative of colonialism, but revisits it using a different lens. Unlike colonial discourses, postcolonial theory does not privilege the colonial experience, but rather, retrieves this history from the perspectives of the formerly colonised (or the Other).

The concept of the 'Other' has invariably been used to produce categories and images of non-European populations as appropriate (and convenient) to the political, legal, economic, and social state of Western civilisation at a given epoch. $^{25}$ It is this phenomenon that has led Césaire ${ }^{26}$ to observe that the only history is white, and Fanon, Said, Spivak, Bhabha, among other postcolonial theorists, to reject the humanist notion of a totalising universal history, as (after all) it has always been 'European Man' at the centre of it. ${ }^{27}$ These theorists have argued that race is a social construct as the 'norm' (that is 'the European Man') has been defined through the creation of the Other. Moreover, they have questioned the use of 'human' as an explanatory category that purports to provide a rational understanding of 'man': an assumed universal predicated on the exclusion and marginalisation of his Others.

The term 'Other' is a key concept in postcolonial theory. ${ }^{28}$ The textual construction of the term 'Other' can be traced to the dualistic thought structures of Western epistemologies, where ideas were essentially formed around Hegelian binary oppositions (such as man/woman, positive/negative, white/black, and so on). However, as Derrida has now famously declared, these philosophical oppositions did not exist in 'peaceful' neutrality, but rather, were formed within a 'violent hierarchy' of difference — where the dominant term was (is) constructed by the

25 This is the central theme in Edward W Said's foundational text Orientalism: Western Conceptions of the Orient (1995). Orientalism was originally published in 1978. Said's work will be discussed in further detail below. See Aimé Césaire, Discourse on Colonialism (2000).

For a very readable account of how this 'general theme' has impacted on legal discourse (and has caused 'the dissolution of legal theory'), see Davies, above n 3, 167-351.

For further explanation on the use of the term 'Other' (or 'other') in postcolonial theory, see Bill Ashcroft, Gareth Griffiths and Helen Tiffin, Post-Colonial Studies: the Key Concepts (2nd ed, 2000) 169-71. Please also note Jacques Lacan's differentiation between the terms 'Other' and 'other'. 
exclusion of the subordinate one (or, its Other). ${ }^{29}$ These dichotomous structures continued throughout colonialism, where non-European Others were relegated to being mere objects of history (as they were simply incapable of being its subjects). ${ }^{30}$ One of the aims of postcolonial theory has been to deconstruct the source of these Western epistemologies, and reconstruct new meanings in discourse and dialogue. Indeed, to some extent, postcolonial theory has been in the practice of creating its own meaning in language, in order to be able to explain fully its intellectual project. ${ }^{31}$ On this point, it should be noted that postcolonial theory has attracted negative comment with respect to its apparent narcissism: it has been perceived by some as yet another way in which high European theory continues its conversation (with itself) to explain the Other. ${ }^{32}$

Postcolonial critique is united by the belief that Western colonialism - with its control of most of the world from around 1492 till the end of the Second World

Jacques Derrida, Positions (1981) 41.

Enrique Dussel explains this idea further. Dussel suggests that the central position occupied by Europe in the world-system is not due to 'an internal superiority accumulated during the European Middle Ages' over other cultures. Rather, it is the result of processes such as conquests and colonisation, which positions Europe in a 'comparative advantage over the Ottoman-Muslim world, India, and China': See Enrique Dussel, 'Beyond Eurocentrism: the World-System and the Limits of Modernity' in Jameson and Miyoshi (eds), The Cultures of Globalization (1998) 331, 4-5.

For reference texts which explain several of the key concepts and terms used in postcolonial theory, see Ashcroft, Griffiths and Tiffin, Post-Colonial Studies: the Key Concepts, above n 28; John C Hawley, Encyclopedia of Postcolonial Studies (2001). It should be noted that the language used in postcolonial theory is often criticised for being esoteric, dense, and impenetrable. This is not merely a question of the style chosen by postcolonial theorists. The theoretical-historical trajectory of postcolonial theory is both hybrid and vast. As a result, its language is drawn from a wide range of disciplines, including: anthropology, cultural studies, feminism, history, human geography, Marxism, philosophy, poststructuralism, psychoanalysis, sociology, and structuralism.

Indeed, given the ideological project of postcolonialism (namely — its opposition to Eurocentrism), its intense engagement with European theories is often queried. As Mignolo points out, the structuralists and poststructuralists are still Eurocentric. See Walter D Mignolo, 'Globalization, Civilization Processes, and the Relocation of Languages and Cultures' in Jameson and Miyoshi (eds), The Cultures of Globalization (1998) 32-53, 48. In defence of postcolonial theory, Young suggests that ' $[\mathrm{p}]$ ostcolonialism is neither western nor non-western, but a dialectical product of interaction between the two'. Moreover, postcolonial theory is a hybrid product of Western and non-Western anti-colonialism. Significantly, according to Young, anticolonialism was not exclusively a non-Western phenomenon - colonialism was also heavily critiqued (and resisted) in the West. For example, both Gandhi and Fanon drew on Western anti-colonial critiques: Gandhi utilised the New Testament, Carpenter, Ruskin, Spengler, Thoreau and Tolstoy; Fanon drew from psychoanalysis and Marxism, particularly existential Marxism. See Young, above n 6, 68. 
War - was not an ordinary state of affairs, but rather, an extraordinary one. ${ }^{33}$ Scholars such as Ernest Gellner argue that colonialism in itself was no different from other forms of oppression, or other conquests in the past. ${ }^{34}$ Gellner asserts that 'the recent domination of the world by the west can be seen ... as primarily an aspect of the transformation of the world by a new technology, economy, and science which happens ... to engender a temporary and unstable imbalance of power'. ${ }^{35}$ However, to argue that colonialism was a mere casualty of modernity is to ignore the enormity of the imperial project. Colonialism was not simply about technology, economy, and science; it was also about ideological and racial domination, Eurocentrism as 'truth', and the essential marginalisation of most of the globe.

While several examples of colonialism and imperialism may be found, contemporary postcolonial discourse is concerned with the specific brand of Western colonisation which began before (and continued throughout) the European Enlightenment. The coterminous (and indeed, overlapping) temporal boundaries of colonialism and the Enlightenment period are highly significant. The Enlightenment witnessed the flourishing of progressive social movements, a renewed interest in the concept of democracy, the advancement of scientific and technical knowledge, and the promotion of a secular worldview. However, it was during this age of high European humanism where the concept of the Other developed, and gradually gained acceptance (at least among the Europeans) as a 'universal truth'. ${ }^{36}$

It was also during the Enlightenment that the concept of 'race' as a construct emerged. From the late $17^{\text {th }}$ century, European scholars began to classify the human race into four or five broad groupings. ${ }^{37}$ A number of factors led to this development, including: the need to justify colonialism and slavery; an increased scholarly interest in natural history; and a desire to understand and construct the

For an overview on the way in which the colonial and imperial powers had dividedup the globe during this time, see generally Young, above n 6, 2-11.

See Ernest Gellner, 'The Mightier Pen? Edward Said and the Double Standards of Inside-out Colonialism' (1993) Times Literary Supplement 3.

Ibid.

Interestingly, Adorno and Horkheimer suggest that because 'the Enlightenment has always sympathized with the social impulse', it was able to produce both liberalism as well as fascism. See Theodor W Adorno and Max Horkheimer, Dialectic of Enlightenment (2nd ed, 1986) 13.

Robert Bernasconi suggests that in 1684, an anonymous paper (usually attributed to Francois Bernier) classified the human race into different types: while they were not all given names, they corresponded 'roughly to Europeans, Africans, Orientals and Laplanders, while allowing for the possibility of two additional types, the Native Americans and the Hottentots.' The paper was also one of the first to use the word 'race'. See Robert Bernasconi, 'Who Invented the Concept of Race? Kant's Role in the Enlightenment Construction of Race' in Bernasconi (ed) Race (2001) 12. 
world in taxonomic terms. ${ }^{38}$ It is not at all surprising that this taxonomy of humanity was intensely hierarchical (with the European (Man) placed firmly on top), and was also heavily loaded with a Eurocentric world view. ${ }^{39}$ Significantly, this belief was further strengthened in the $19^{\text {th }}$ century with the emergence of social Darwinism. $^{40}$

Debates at the heart of contemporary postcolonial legal theory focus on the role of the law as an integral component of the colonial, imperial, and now postcolonial projects. As colonial laws were products of the colonising power, they were exported to the territories of the Other (regardless of whether the Other recognised the legitimacy of those laws). The laws were also used to govern legal relations between various European colonial powers, and operated in the words of Jennifer Clarke as 'a code of honour among thieves. ${ }^{41}$ During this time, international law (another Western construct) recognised three methods of colonial territorial acquisition: conquest, cession, and settlement. Under the first two methods, the existing laws in the acquired territory would continue in force until they were changed by the new sovereign. However, the situation with respect to settled lands was different. In a frequently quoted passage, Sir William Blackstone in the 18th century stated in his Commentaries:

38 Taxonomy involves the classification of organisms into an ordered system. Bernasconi suggests that the first theorist to include humans within the grand scheme of natural classification of animals and plants was the $18^{\text {th }} \quad$ century Swedish researcher, Carolus Linnaeus (1707-1778). Linnaeus is primarily known as the founder of the system of binomial nomenclature used for naming species. $\mathrm{He}$ published twelve editions of his Systema naturae sive regna tria naturae throughout the $18^{\text {th }}$ century. Bernasconi suggests that although Linnaeus did not explicitly organise the racial groups hierarchically, the higher status of the homo Europaeus is implicit in his analysis. See Bernasconi, above n 37, 15.

For examples of some of these views held by leading Western philosophers, such as Hume, Kant, and Hegel, see Dinesh D'Souza, The End of Racism: Principles for a Multiracial Society (1995) 28-29. Bernasconi also remarks that Kant's writings today would 'unquestionably be characterized as racist.' See Bernasconi, 'Who Invented the Concept of Race? Kant's Role in the Enlightenment Construction of Race', above n 37, 14.

40 Social Darwinism is a theory of organic evolution which claimed that new species arise and are perpetuated by natural selection. In the context of humans, this would mean that the stronger races would inevitably replace the weaker ones. European evolutionary theory at this time categorised the human race within a hierarchy of different stages, where different races would gradually 'progress' through these various phases of human evolution. For further discussion on the concept of Social Darwinism, see Mike Hawkins, Social Darwinism in European and American thought 1860-1945: Nature as Model and Nature as Threat (1997); Peter Dickens, Social Darwinism: Linking Evolutionary Thought to Social Theory (2000). and Parker (eds), Law in Context (2nd ed 1997) 231-75, 246. 
[I]t has been held, that if an uninhabited country be discovered and planted by English subjects, all the English laws then in being, which are the birth-right of every subject, are immediately there in force. ${ }^{42}$

Thus, in settled colonies, the laws of the colonial power would be in force on settlement.

Curiously, Australia was declared to be terra nullius or uninhabited, despite the actual existence of Indigenous peoples residing in the colony at the time. Under (Western) international law, the declaration of terra nullius meant that Australia was available for settlement, and British law would operate in the new colony. The historical fact of Indigenous peoples residing in Australia at the time was a minor interference to settlement plans. Significantly, from a postcolonial view, whether or not these laws were recognised by Indigenous peoples was not really relevant: the laws were simply transported to the annexed territories as part of the colonial project.

The Supreme Court of New South Wales held fairly early in the history of the colony that it had jurisdiction to deal with Mr Murrell, an Aborigine, who was charged with the murder of another Aboriginal person. Interestingly, Mr Murrell's counsel put forward the following argument to the Court, which was subsequently rejected:

This country was not originally desert, or peopled from the mother country, having had a population far more numerous than those that have since arrived from the mother country. Neither can it be called a conquered country, as Great Britain was never at war with the natives, not a ceded country either; it, in fact, comes within neither of these, but was a country having a population which had manners and customs of their own, and we have come to reside among them; therefore in point of strictness and analogy to our law, we are bound to obey their laws, not they to obey ours. ${ }^{43}$

While Australia's status as a settled territory was confirmed by the Privy Council in 1889 in Cooper $v$ Stuart $^{44}$, the doctrine of terra nullius was significantly overturned by the High Court in Mabo v Queensland (No 2). ${ }^{45}$ In this landmark decision, the High Court formally acknowledged - for the first time in Australia's Western legal history - that Indigenous people did in fact have a relationship to the land, which was recognised by law (that is the Court accepted a claim to 'native title'). However, from a postcolonial perspective, scholars such as Davies point out that

\footnotetext{
42 William Blackstone, Commentaries on the Laws of England: Volume I (2001) 107.

43 $R v$ Murrell (1836) 1 Legge 72 at 72; cited in Northern Territory Law Reform Committee, Background Paper 2: The Recognition of Aboriginal Law as Law (NTLRC, Darwin, 2003) 9.

$44 \quad$ (1889) 14 App Cas 286.

45 (1992) 175 CLR 1 ('Mabo')
} 
'the decision was qualified by the fact that native title was recognisable within Australian (that is, colonial) law. ${ }^{46}$ Using the existing (dominant) framework of Western law, the Court merely created a new fiction: 'native title'. ${ }^{47}$ In other words, the concept of 'native title' was constructed as yet another Western legal fiction (like terra nullius) in order to understand Indigenous law. In postcolonial terms, Western legal discourse continued its conversation (with itself) to explain the Other - regardless of the Other's own position in this dialogue (or indeed, whether the Other had in fact decided to enter into the dialogue at all) Positioning herself from outside the dominant (Western) legal narrative, Davies points out that none of the seven judges in Mabo was willing to question the legitimacy of the actions which led to the establishment of the Australian state. ${ }^{48}$ Indeed, as stated by Brennan J's leading judgment in Mabo, to do so would be to rupture 'the skeleton of principle which gives the body of our law its internal shape and consistency. ${ }^{49}$ On this point, Watson remarks that '[t]he real death of terra nullius would have dismantled the Australian legal system', as its 'real death' would have caused the disintegration of the legal foundations on which the Australian state is based. ${ }^{50}$

Despite this postcolonial criticism of Mabo, the case was certainly radical in its attempt to find an appropriate legal remedy for the dispossession of Aboriginal peoples from their traditional lands - albeit within the exceedingly restrictive confines of Australia's Western legal framework. Significantly (and rather depressingly) there has been a steady decline in the recognition of native title rights in this country - made evident by developments in both case law and legislation. While the Court in Mabo recognised a claim to native title, the judgment made it clear that this title could be readily extinguished (both wholly or partially) by numerous and various acts of appropriation. ${ }^{51}$ Indeed, the very precarious nature of native title was recognised by Brennan $\mathrm{J}$ himself in his later judgment in Wik Peoples $v$ Queensland: ${ }^{52}$

Its weakness is that it is not an estate held from the Crown nor is it protected by the common law as Crown tenures are protected against impairment by subsequent Crown grant. Native title is liable to be extinguished by laws enacted by, or with the authority of, the legislature or by the act of the executive in exercise of powers conferred upon it.

Davies, above n 3, 275.

Ibid.

Ibid.

Mabo v Queensland (No 2) (1992) 175 CLR 1, 29 (Brennan J) ('Mabo').

Watson further asserts that '[t]erra nullius has not stopped; the violations of our law continue, the ecological destruction of the earth our mother continues with a vengeance, we are still struggling to return to the land, and the assimilator-integrator model is still being forced upon us.' Watson, above, n 12, 48. For a useful background to Australian Aboriginal peoples and the legal system, see Bottomley and Bronitt, above n 18, 276-310. See Mabo (1992) 175 CLR 1, 63-71 (Brennan J). (1996) 187 CLR 1, at 84 
Nevertheless, despite the very limited right recognised by the Court in Mabo, the case "was met with howls of derision from many quarters. ${ }^{53}$ As Melissa Castan and Sue Kee state:

The litany of woes ranged across the spectrum ... culminating in almost hysterical headline claims in country, state and national newspapers threatening the dire collapse of the Australian economy and polity. ${ }^{54}$

Following extensive negotiations between the Commonwealth Government, the Indigenous community, and non-Indigenous interest groups, the Keating Labor government responded to Mabo by enacting the Native Title Act 1993 (Cth). ${ }^{55}$ However, the intense criticism of both the Mabo decision, and the Native Title Act 1993 (Cth), resulted in the newly elected Howard Coalition government subsequently enacting the Native Title Amendment Act 1998 (Cth). This Act not only severely curtailed the scope of native title recognition in this country, several questions were also raised as to its validity under both the Australian Constitution and international laws. ${ }^{56}$ Moreover, the legal complexity and technicality of the Native Title Amendment Act 1998 (Cth), with its need for 'senior legal and anthropological experts', means that it is well 'beyond the present financial resources of the entire Indigenous polity, ${ }^{57}$ Importantly, a large number of native title cases since the Mabo decision have not only confirmed the primacy of the Native Title Acts, but have also served 'to reinforce the perfidious consequences of dispossession and the elusiveness of gaining effective common law recognition of native title. $^{58}$

53 Melissa Castan and Sue Kee, 'The Jurisprudence of Denial' (2003) 28 Alternative Law Journal 83, 83.

54

Ibid.

Note that the constitutional validity of this Act was unsuccessfully challenged by the Western Australian state Liberal government in Western Australia v Commonwealth (1995) 183 CLR 373.

See Garth Nettheim, 'The Search for Certainty and the Native Title Amendment Act 1998 (Cth)' (1999) 22 University of New South Wales Law Journal 564; Gillian Triggs, 'Australia's Indigenous Peoples and International Law: the Validity of the Native Title Amendment Act 1998 (Cth)' (1999) 23 Melbourne University Law Review 372.

Castan and Kee, above n 53, 84.

Ibid. See, eg, Members of the Yorta Yorta Aboriginal Community v Victoria [2002] HCA 58 (12 December 2002) ('Yorta Yorta'); Western Australia v Ward (2002) 213 CLR 1; Wilson v Anderson (2002) 213 CLR 401. For criticism of the majority view in Yorta Yorta with respect to the concept of 'traditional' connections to the land, see Castan and Kee, above n 50, 84-87. For an interesting discussion on the 'space' which exists between the common law and native title, see Noel Pearson, 'The Concept of Native Title at Common Law' in Yunupingu (ed) Our Land is Our Life: Land Rights- Past, Present and Future (University of Queensland Press, St Lucia, 1997) 150-62. 
From a postcolonial perspective, Australia provides a very interesting example of the way in which the law operated during the colonial process. Not only were Western laws used to justify the annexation of vast non-Western territories, it was simply irrelevant to the colonial project whether or not the Other recognised these laws. Moreover, the laws were simply ignored when it became necessary to do so - as was the case in this country.

As noted earlier, various Eurocentric theories were used legally to support and rationalise European expansionism during the colonial era. John Locke's labour theory of property is of particular interest in the postcolonial context. In the late $17^{\text {th }}$ century, the English philosopher argued in The Second Treatise of Government that property was gained from mixing one's labour with natural resources. ${ }^{59}$ According to this theory, there could be 'no property' without the true mixing of labour (that is appropriating and transforming the land). ${ }^{60}$ In other words, hunting and gathering of resources on land was not enough to constitute the 'property' of it. As the vast majority of Indigenous groups were nomadic hunters and gatherers, this theory of property was used essentially to delegitimise and invalidate Indigenous systems of land 'ownership' and 'occupation'. ${ }^{61}$ The theories of Vattel were also used to justify colonialism, by appealing to both natural law and Christianity. The following passage by Vattel has frequently been quoted:

[T] hese tribes can not take to themselves more land than they have need of or can inhabit and cultivate. Their uncertain occupancy of these vast regions can not be held as a real and lawful taking of possession; and when the Nations of Europe, which are too confined at home, come upon lands which the savages have no special need of and are making no present and continuous use of, they may lawfully take possession of them and establish colonies in them. ${ }^{62}$

In the $19^{\text {th }}$ century, theorists such as Karl Marx and Henry Maine endorsed notions of European legal superiority by promoting the view that 'mankind' would eventually progress from the disorderly kinship relations of small-scale societies, and evolve into a more orderly and rational system of predictive laws. ${ }^{63}$ Indeed, in

See 'Of Property' (ch 5) in John Locke, Two Treatises of Government (1993) [27].

With respect to Locke's views on property, see ibid [25]-[51].

61 These terms have been placed in quotation marks as there are fundamental differences between Indigenous and non-Indigenous groups as to the meaning of these words. See generally Australian Law Reform Commission (ALRC), The Recognition of Aboriginal Customary Laws: Report No 31 (1986), The Report is available online: <http://www.austlii.edu.au/au/other/IndigLRes/1986/1/> at 12 April 2007; Northern Territory Law Reform Committee, Background Paper 1: Aboriginal Communities and Aboriginal Law in the Northern Territory (2003); John Toohey, Background Paper on Aboriginal Customary Laws Reference: An Overview (2004). Vattel, The Law of Nations, Book 1, ch 18, reprinted in Alex Castles and JH Bennett, A Source Book of Australian Legal History (1979) 251. Tradition (1990) 264-9. 
the $19^{\text {th }}$ century, the law could (and did) provide a regulatory framework in which individuals and nation-states could be categorised and 'rationalised' into the liberal positivist system of law. ${ }^{64}$ During this time, Darian-Smith suggests that as a concept, the legal subject was 'naturalized as part of modernity's overriding common sense' and used as 'a justification for colonialism. ${ }^{65}$ From a postcolonial perspective, it is clear that the portrayal of Western legal systems as superior has not been confined to history, but continues in contemporary legal thought in this era of postcolonialism. ${ }^{66}$

As colonial legal systems were an instrumental part of the imperial project, European laws were established as the natural default for the colonised world. This hegemony of European laws could be seen in conquered, ceded and settled territories, and across various areas of law. For example, in the field of intellectual property, Peter Drahos suggests that the 'transplant of intellectual property laws to developing countries has been the outcome of processes of empire-building and colonisation. ${ }^{67}$ The significance of territories being forcibly annexed, and then subjected to foreign political and cultural norms — including legal systems should not be underestimated. Indeed, it is simply naive to assume that Western cultural and legal structures have been encumbered by the Other without an enormous impact on local cultures. ${ }^{68}$ After all, the laws of a culture essentially reflect the underlying values of that society, by defining what is to be protected, how, and for how long. In the words of Alexander Bickel, '[1]aw is the principal institution through which a society can assert its values. ${ }^{69}$

For these reasons, postcolonial legal scholars claim that Western laws are, not surprisingly, infused with Western values — such as liberalism. For example, in her

See Boaventura de Sousa Santos, Toward a New Legal Common Sense: Law, Globalization, and Emancipation (2002) 40-4.

Eve Darian-Smith, 'Myths of East and West: Intellectual Property Law in Postcolonial Hong Kong' in Goldberg and Quayson (eds), Relocating Postcolonialism (2002) 294-319, 303. Ibid. See generally Fitzpatrick, above n 19.

67 Peter Drahos, 'Negotiating Intellectual Property Rights: Between Coercion and Dialogue' in Drahos and Mayne (eds), Global Intellectual Property RightsKnowledge, Access and Development (2002) 161-82, 164. Ruth Gana also suggests that with the exception of the Universal Copyright Convention, most of the former colonies were automatically bound by the major intellectual property treaties once the treaty was ratified by the colonial power. See Ruth L Gana, 'Has Creativity Died in the Third World? Some Implications of the Internationalization of Intellectual Property' (1995) XXIV Denver Journal of International Law and Policy 109, 124 (n 65).

As Darian-Smith suggests, although 'many Western scholars remain steadfastly unaware of the political and social implications of their own sociolegal paradigms, many non-Western scholars are acutely aware of the ongoing epistemic violence and its effects at the local level.' See Darian-Smith, above n 62, 312. Alexander M Bickel, The Morality of Consent (1975) 5. 
discussion of the United Nations (UN), Dianne Otto suggests that while the international organisation declares to be founded on universal principles, with universal application, its fundamental goals clearly reflect the ideals of the European enlightenment. ${ }^{70}$ Similarly, Mohammed Bedjaoui, a former President of the International Court of Justice, also asserts that far from being neutral, international laws during the colonial era 'consisted of a set of rules with a geographical basis (it was a European law), a religious-ethical inspiration (it was a Christian law), an economic motivation (it was a mercantilist law) and political aims (it was an imperialist law). ${ }^{71}$ From a postcolonial perspective, it is significant to note that not only were (are) European laws imbued with European values, the inherent superiority of these laws were (are) subsequently juxtaposed against the irrational and 'barbaric' laws of the Other. In true Hegelian dialectical style the 'law, at least the symbolic value of a rationalized law, became a marker and pivot on which cultural difference was then ranked. ${ }^{72}$ In this way, the law has played a constitutive role - along with other forms of knowledge — in defining the colonial subject. Indeed, as illustrated by philosophers such as Michel Foucault, hegemonic power is operative through its complicity with knowledge, and the law not only legitimises the dominant distributions of power, it is also a central locus through which the Other is constructed (and then delegitimised). ${ }^{73}$

\section{THE TEMPORAL BOUNDARIES OF POSTCOLONIAL THEORY}

The location of postcolonial theory and law as discourses has been canvassed above. The purpose of this section is to outline briefly the four key terms which define postcolonial theory's temporal and spatial boundaries: colonialism, imperialism, neocolonialism, and decolonisation. It is necessary for legal scholars (and others) to have a clear understanding of these major historical concepts if they are to engage with postcolonial critique in any meaningful way. Moreover, a discussion (albeit brief) of these key concepts is important, as an explanation of these terms is often neglected, and the meaning implied by them frequently misunderstood.

In particular, the terms 'colonialism' and 'imperialism' are often used interchangeably - even by theorists engaged in postcolonial theory. This can be explained partly by the fact that some of the foundational scholars in

70 This is particularly ironic as the UN was established in the postcolonial era. Dianne Otto, 'Subalternity and International Law: the Problems of Global Community and the Incommensurability of Difference' (1996) 5 Social \& Legal Studies 337, 339, $351-2$.

Mohammed Bedjaoui, 'Poverty of the International Order' in Falk, Kratochwil and Mendlovitz (eds), International Law: a Contemporary Perspective (1985) 152-63, 154.

See Michel Foucault, Power/knowledge: Selected Interviews and Other Writings, 1972-1977 (1980). 
postcolonialism, such as Edward Said, ${ }^{74}$ and Frantz Fanon, ${ }^{75}$ did not differentiate between colonialism and imperialism, or their different forms. As a result, contemporary postcolonial theory has largely been drawn from relatively singular notions of the colonial process, and then applied universally to most colonial and postcolonial situations. Nevertheless, although the practices of these two forms of domination cannot clearly be demarcated, there are significant differences between the two. These will be outlined below.

\section{A. Colonialism and Imperialism}

Professor Young has very usefully traced some of the dissimilarities between colonialism and imperialism in his comprehensive study. ${ }^{76}$ Young suggests that in broad terms, 'imperialism' generally referred to a structure of government which was bureaucratically controlled from a metropolitan centre. ${ }^{77}$ On the other hand, 'colonialism' usually referred more to settlements which were established for commercial purposes by a trading company, or developed for individual communities as territories away from 'home'. ${ }^{78}$ Until the $19^{\text {th }}$ century, colonialism generally developed locally in a fairly erratic fashion, ${ }^{79}$ while imperialism was more ideologically driven and concerned itself with the extension of state power. ${ }^{80}$ Colonialism was also a more peripheral activity, fuelled mainly by trade and economics. As the imperial process was generally more ideologically driven, it concerned itself with grand notions of power, domination, and sovereignty. Given these fundamental differences, Young suggests that imperialism is best described as a 'concept', while colonialism is more of a 'practice'. ${ }^{81}$

Apart from the Spanish and Portuguese expeditions to Central and South America, the early colonial powers (namely, the British and the Dutch) did not initially justify colonisation in terms of missionary work, or related Eurocentric aims. ${ }^{82}$ This is because they were either 'indifferent, or liberal relativists, or because racial

Said, above n 25 .

Fanon, above n 14; Frantz Fanon, The Wretched of the Earth (1963); Frantz Fanon, $A$ Dying Colonialism (1965); Frantz Fanon, Toward the African Revolution: Political Essays (1967). Fanon's work will be discussed in detail below.

See Young, above n 6, 15-24, for a discussion on colonialism; and 25-43, for a discussion on imperialism.

Ibid 16.

Ibid.

For example, it was not until 1849 that Wakefield proposed a system of organised colonisation, which was used for South Australia and New Zealand. See his letters in Edward Gibbon Wakefield, A View of the Art of Colonization, in Letters Between a Statesman and a Colonist.

Young, above n 6, 16.

Ibid 17.

The grand European colonial enterprise (including missionary colonialism) was more a product of $19^{\text {th }}$ century imperialism. See Ibid 22, 24 . 
prejudice meant that they preferred extermination to affiliation'. ${ }^{83}$ Young suggests that Eurocentric values came as a 'by-product' to the major project of colonisation, which was 'trade, economic exploitation and settlement. ${ }^{84}$ Indeed, the critical motivating factor for Britain to colonise and expand its territories overseas was the fundamental problem of overpopulation. ${ }^{85}$

There have been two major forms of colonialism according to Young: first, lands colonised for the purpose of settlement, such as Australia, New Zealand, and North America; and, second, lands colonised for economic exploitation, without any major settlement, such as India, the Philippines and New Caledonia. ${ }^{86}$ Interestingly, in several exploitation colonies, colonial administration followed the activities of the trading companies once these companies had already established their presence in the colonies. ${ }^{87}$ The role played by companies in the colonial game remains a key feature in this era of postcolonialism. ${ }^{88}$

Young suggests that historically, there have been two major forms of imperialism as well (not including the contemporary United States form): first, the Roman, Ottoman and Spanish model $;^{89}$ and, second, the late $19^{\text {th }}$ century European form. ${ }^{90}$ Within the European powers, the British and the French models of colonial and

83

Ibid 24.

Ibid.

Young suggests that centuries before Malthus, Britain was believed to have an unsustainable population, which reached dangerous levels in the famine-stricken 1840s. The transportation of convicts also continued until 1867, which served the dual purpose of population control, and eliminating the 'undesirables' from British society. See ibid 22.

Young notes that Jurgen Osterhammel argues for the inclusion of a third type of colonialism: 'maritime enclaves'. These included islands and other strategic points which were occupied for naval and military purposes, sometimes also with the aim to trade with a mainland. For example, Hong Kong, Singapore and Malta. However, as the commercial activities in these enclaves developed, they generally evolved into a type of exploitation colony (Young's second form of colonialism). See Jurgen Osterhammel, Colonialism: A Theoretical Overview [1995] (Marcus Wiener, Princeton, NJ, 1997); cited in Young, above n 6, 17.

For example, the East India Company, which developed into the British Empire; and the Virginia Company, which developed into the North American colonies. Miyoshi also suggests that US dominance over Central America was largely achieved through the United Fruit Company. See Masao Miyoshi, 'A Borderless World? From Colonialism to Transnationalism and the Decline of the Nation-State' (1993) 19 Critical Inquiry 726, 749.

For example, Miyoshi argues that transnational corporations continue colonialism in this postcolonial era. See Ibid.

The first modern European 'empire' was created by the Spanish. The Spanish empire was based on the Roman and Ottoman model, which was a highly bureaucratic and pre-capitalist form of rule involving direct taxation of subject peoples, administered by a combination of political and military control. See Young, above n 6, 17, 25. Ibid 17. 
imperial rule were dominant up to the $20^{\text {th }}$ century. The French policy of 'assimilation' was embraced by the Russians, Italians, Portuguese, and the Americans (as colonisers). ${ }^{91}$ While the British policy of 'association' was adopted by the Germans, the Dutch, and the Americans (as imperialists). ${ }^{92}$ It should be noted, however, that other imperial powers (such as Germany, Italy, Japan, and Russia), each had their own unique form of imperialism, accompanied with national idiosyncrasies, and distinctive notions of imperial domination and control.

The momentum caused by the anti-colonial struggles during the First World War continued right until the Second World War, when it eventually became clear that the old imperial system - in the form of direct domination, was no longer sustainable. ${ }^{93}$ Unlike colonialism, which was established primarily for economic exploitation, imperialism has proved to be monetarily very inefficient and unprofitable. ${ }^{94}$ By the Second World War, 'imperialism' referred to an ideology and system of economic domination associated with the US, whereas 'colonialism' referred to the old European colonial powers and their political domination over subject peoples. After the Second World War, the European powers adopted the US form of imperialism, by granting their colonies political independence while still

91 The French policy of assimilation ensured that the French overseas territories were treated administratively and conceptually as part of France. The mission civilisatrice underlay the policy of assimilation in French imperial rule. The purpose of the mission civilisatrice was to export French culture to its overseas territories. Young suggests that the French doctrine of assimilation was a 'paradox of ethnocentric egalitarianism', as there was both a belief in the fundamental equality of humankind, and also a belief in the fundamental 'backwardness' of colonised peoples. Although there were some exceptions and modifications to the general policy of assimilation (such as in Algeria and Indo-China), it very much remained the dominant guiding principle for French imperialism up to the $20^{\text {th }}$ century: See ibid 29-30, 32.

The British imperial policy of 'association' (or non-interference) with local cultures (as compared to the French policy of assimilation - discussed above n 88), was based on racist assumptions of the incapacity of the Other to learn European ways. In contrast to the French model of imperialism, which was highly centralised and bureaucratic, the British form of control was far more erratic. Young suggests that one of the main reasons for this was that private companies (as opposed to state actors) were responsible for a significant portion of the British imperial project. The colonies were administered by three separate government offices (the Colonial Office, the Foreign Office, and the India Office). There were also several different types and classes of colonies, which were generally administered by Britain at the local level. The British Empire rapidly expanded in the latter part of the $19^{\text {th }}$ century, turning it into an enormous decentralised structure which was often very difficult to control: See ibid 26, 33-5. See Franz Ansprenger, The Dissolution of the Colonial Empires (1989). was 'the rising costs of empire'. P J Cain and A G Hopkins, British Imperialism: Crisis and Deconstruction, 1914-1990 (1993) 286. 
maintaining economic control. Today, the US is the only remaining Western imperial power. ${ }^{95}$

\section{B. Decolonisation}

The process of decolonisation essentially involves the change of status in a territory from colonial to independent. The arbitrary cartographic lines drawn by the colonisers during the colonial process, irrespective of pre-colonial identities and organisation, resulted in various peoples to either forcibly join, or fragment. The process of decolonisation resulted in the same effect, where a new legal fiction of statehood was inscribed upon a former colonial space.

The territorial boundaries of imperial rule were legitimised by the international legal principle of uti possidetis (or, the unalterability of colonial frontiers). ${ }^{96}$ The essential meaning behind the principle of uti possidetis is that the sovereignty and territorial limits of the newly independent nation-state is fixed absolutely on independence, due to the unalterability of colonial frontiers. ${ }^{97}$ Ironically, the process of decolonisation results in the same effect.

From a postcolonial perspective, it is important to note that the principle of uti possidetis and the idea of the modern nation-state are both Western constructs, which have been packaged and forcibly exported around the globe. As Dianne Otto suggests, decolonisation resulted in the prerequisites for the existence of a nationstate to be re-conceptualised along Western lines, based on a centrally organised system of government and control. ${ }^{98}$ Often this meant that in the former colonies, there was a shift in the primary loyalty of a citizen from family, community or religious ties, to the nation-state. Indeed, the idea of the modern nation-state was superimposed upon diverse communities and multiplicitous identities. ${ }^{99}$ Moreover,

US imperialism represents a shift away from the 'traditional' old-style forms of European imperialism, and is characterised by indirect economic and political rule. From 1898 to the First World War, there was a change in US policy from acquisition of contiguous land through military settlement, to one of direct acquisition of overseas colonies (based on the European model). For instance, the US victory in the Spanish-American War of 1898 resulted in America acquiring most of Spain's remaining colonies, such as the Philippines, Puerto Rico and Cuba. The US continued to acquire non-contiguous territories in the $19^{\text {th }}$ and $20^{\text {th }}$ centuries, such as: Alaska, the Aleutian and Midway Islands in 1867; American Samoa in 1878-99; Guam, the Philippines, Puerto Rico, the Hawaiian and Wake Islands in 1898; the Panama Canal Zone in 1903; the Virgin Islands in 1917; and occupied as 'protectorates' Nicaragua, Panama, Cuba and the Dominican Republic from 1903 to 1915. See Young, above n 6, 41-43.

Otto, above n 70, 341. The principle of uti possidetis is derived from Roman law.

Peter Butt (ed) Butterworths Concise Australian Legal Dictionary (3rd ed, 2004) 446. Otto, above n 70, 341 .

One of the most influential contemporary texts on the idea of the nation-state is Benedict Anderson, Imagined Communities: Reflections on the Origin and Spread of 
the construction of the idea of the modern nation-state was not a neutral exercise. Rather, this involved the construction of another 'violent hierarchy', ${ }^{100}$ as the 'superiority of the modern nation-state was thus juxtaposed with the traditional social formations that predated the civilizing mission of the European colonists around the globe.' ${ }^{101}$ Thus, for the Other, it was necessary (yet again) to conform to the Westcentric model of statehood in order to be eligible for independence, and be recognised as a modern nation-state.

The majority of the former colonies decolonised in the decades following the end of the Second World War - particularly in the 1950s and 1960s. However, as noted earlier, independence struggles continue in various former colonies.

\section{Neocolonialism}

The term 'neocolonialism' was introduced in 1961. ${ }^{102}$ The term was coined by the first President of independent Ghana, Kwame Nkrumah, and essentially implies that although former colonies have technically achieved independence, the former colonial power (and also newly emerging superpowers, such as the United States), continues to perpetuate influence (economic, political, and social) on the former colony. ${ }^{103}$ Nkrumah was one of the leading exponents of neocolonial theory, and he discussed the concept extensively in his 1965 text, NeoColonialism: The Last Stage of Imperialism (discussed below). ${ }^{104}$

While the concept of neocolonialism has at times been used as an alternative to postcolonial theory, it has mainly been exploited to provide a Marxist economic analysis of the postcolonial condition. ${ }^{105}$ Indeed, neocolonialism is most heavily

Nationalism (Rev ed, 1991). Anderson argues at 113 that there was an international dependency on European models of the nation-state in the colonies, where American and European experiences were 'everywhere modularly imagined'. His thesis has been critiqued by several postcolonial theorists, notably by Partha Chatterjee. Chatterjee asserts that his 'central objection' to Anderson's thesis is that only Europe and the Americas can be 'the only true subjects of history'. Moreover, as nationalisms around the world have already been imagined by the West, 'we in the postcolonial world shall only be perpetual consumers of modernity' as what is there 'left to imagine?' See Partha Chatterjee, The Nation and Its Fragments: Colonial and Postcolonial Histories (1993) 5.

Derrida, above n 29.

Otto, above n 70, 341.

See Young, above n 6, 46.

See Ashcroft, Griffiths and Tiffin, Post-Colonial Studies: the Key Concepts, above $\mathrm{n}$ 28, 162-3. Ghana was the first African colony to gain independence in 1957, and the term was coined only four years after that event by Nkrumah. are ambiguous (and, in fact, frequently overlap), and there is certainly no clearly 
associated with the continuing economic ramifications of the colonial and imperial projects. ${ }^{106}$ By contrast, postcolonial theory has been used to describe the varied nature of the colonial and imperial process, and has not necessarily focused on one area of critique. In this way, postcolonial theory has aligned itself closely with postmodernism, as both of these critical discourses have commented on the various discursive effects of particular historical conditions. ${ }^{107}$ Moreover, partly due to the burgeoning of postcolonial critique, and partly due to the demise of Marxist ideology (and political systems), neocolonial theory has not flourished in the same way as postcolonial discourse has.

The crux of Nkrumah's argument is that neocolonialism is merely a continuation of colonial rule. In Nkrumah's words, '[t]he essence of neo-colonialism is that the State which is subject to it is, in theory, independent and has all the outward trappings of international sovereignty. In reality its economic system and thus its political policy is directed from outside. ${ }^{108}$ This argument is based on the Hobson model of imperialism, a system of economic exploitation, in which the metropolitan centre depletes the resources of the periphery, while at the same time insisting the periphery consume its manufactured products. ${ }^{109}$ For Nkrumah, '[n]eo-colonialism is ... the worst form of imperialism. For those who practise it, it means power

demarcated line between colonialism and imperialism, neocolonialism and postcolonialism.

While neocolonialism has primarily been used by writers such as Nkrumah to deconstruct economically the postcolonial condition, others have exploited neocolonialism's theoretical framework to develop political and cultural theories grounded in an economic base. For example, Ngugi Wa Thiong'o has focused on the continuing cultural effects of colonialism in areas such as the endurance of colonial languages, and legal and political institutions. Influenced by Fanon, Ngugi argues that the neocolonial elites (who are usually educated in the West) identify more closely with American and European culture than their own. Moreover, the elites often facilitate the regressive and socially irresponsible operations of institutions such as the International Monetary Fund in Africa. See Ngugi Wa Thiong'o, Decolonising the Mind: the Politics of Language in African Literature (James Currey, London, 1986); Ngugi Wa Thiong'o, Moving the Centre: The Struggle for Cultural Freedoms (James Currey, London, 1993).

It is also worthwhile to note that the major postcolonial theorists (such as Fanon, Said, Spivak and Bhabha) have generally positioned their critique from a cultural studies/humanities, and/or psychoanalytic base, as opposed to a purely economic one. It is for this reason that postcolonial theory, unlike neocolonialism, is not overly economic in its analysis of the postcolonial condition, as it has largely based itself within the location of the humanities. Nkrumah, above n 104, ix.

In Nkrumah's words: 'The result of neo-colonialism is that foreign capital is used for the exploitation rather than for the development of the less developed parts of the world. Investment under neo-colonialism increases rather than decreases the gap between the rich and the poor countries of the world.' Nkrumah, above n 104, x. See further JA Hobson, Imperialism: a Study (1988). 
without responsibility and for those who suffer from it, it means exploitation without redress.' 110

While Nkrumah problematically uses the concept of 'neocolonialism' and 'imperialism' fairly interchangeably in his text, and does not significantly challenge the concept of economic development as a Western idea, his exposition of neocolonialism continues to provide an understanding of the fundamental principles of the term.

\section{MAJOR THEMES In POSTCOLONIAL THEORY}

While the temporal definers of postcolonial theory have been discussed above, its theoretical and thematic base will be explored in this section. In order to be able to comprehend at least partially the syncretic topographies of postcolonial theory, and to see what it has to offer law, it is necessary to provide an overview of the major issues and debates at the heart of the discourse. The genealogy of postcolonialism is not only complex, it also has a history of incorporating often contradictory philosophical theories (such as Marxism and poststructuralism). Indeed, there is even little agreement amongst postcolonial scholars as to the precise nature and scope of this heterogeneous field of inquiry.

For these reasons, the major theoretical positions of postcolonial theory are summarised here, and these will (hopefully) provide the reader with the broad academic landscape which has shaped this discourse, and also provide some clues about how it may be used in legal analysis. It should be noted that the discussion below is certainly not exhaustive in its coverage of postcolonial scholarship — it merely represents some of its major scholars and themes. ${ }^{11}$

\section{A. The Beginnings of Postcolonial Theory: The Work of Frantz Fanon}

The Martiniquan psychoanalyst, Frantz Fanon, is most commonly celebrated and acknowledged by contemporary postcolonial theorists as the foundational figure in postcolonial discourse. ${ }^{112}$ In the words of Albert Memmi, he has become 'a prophet of the Third World, a romantic hero of decolonization'. ${ }^{113}$ Indeed, Fanon continues to be revered as one of the most important critics of the practices of colonialism and

\footnotetext{
110 Nkrumah, above n 104, xi.

111 While this section focuses on the prodigious contribution made to postcolonial theory by Fanon, Bhabha, Spivak and Said, it is also important to acknowledge the enormous input made by less renowned postcolonial theorists.

For a comprehensive biography on Fanon, see David Macey, Frantz Fanon: a Life (2000). See also Alice Cherki, Frantz Fanon: a Portrait (2006). Review 9, 39.
} 
imperialism. ${ }^{114}$ Fanon's universal acclaim is partly due to the convergence in his work of the construction of the subject on one hand, and the narrative of colonialism (and postcolonialism) on the other. ${ }^{115}$

Fanon's writing in the 1960s on the psychology of the oppressed, and anti-colonial liberation, challenged the Eurocentric assumptions and world views of that time. ${ }^{116}$ His work also questioned the blatant racism evident in psychological and biological development. Fanon argued that colonialism annihilated and degraded the colonised's sense of self to nothingness - to the extent that 'the black man is not a man. ${ }^{117}$ Fanon is also scathing in his attacks on European progress and humanism:

European achievements, European techniques, and the European style ought no longer to tempt us and to throw us off our balance. When I search for Man in the technique and the style of Europe, I see only a succession of negations of man, and an avalanche of murders ... Let us decide not to imitate Europe. ${ }^{118}$

In his two most influential works: Black Skin, White Masks and The Wretched of the Earth, Fanon is concerned with distinct, but related aspects of the colonial experience. In Black Skin White Masks, Fanon primarily focuses on the psychological impact of colonialism on the colonised. In his other significant work, The Wretched of the Earth, Fanon is concerned with the Algerian resistance to French colonial rule, and anti-colonial liberation struggles more generally. The dual concerns of anti-colonial liberation, and the psychology of the Other, are both intertwined as common themes which are evident throughout much of Fanon's writing.

Fanon's work continues to influence some of the critical themes of postcolonial thought today. For example, his writing on the threatened nature of culture throughout colonisation, the processes of construction by the West of its Other (and the adoption of this version of 'truth' by subjugated peoples), are all major themes in contemporary postcolonial scholarship. ${ }^{119}$ Fanon's revolutionary work on the psycho-social effects of colonialism on both the minds of the colonised and the coloniser continues to impact heavily upon postcolonial studies today, as well as

114 See, eg, Nigel C Gibson (ed), Rethinking Fanon: the Continuing Dialogue (1999). See also Nigel C Gibson, Fanon: the Postcolonial Imagination (2003). See Henry Louis Gates Jr, 'Critical Fanonism' (1991) 17 Critical Inquiry 457, 457-8. See above $n$ 72. Ashis Nandy notes, 'Fanon was one of the first to point out the psychological dominance of the European middle-class culture in the colonies.' See Ashis Nandy, The Intimate Enemy: Loss and Recovery of Self under Colonialism (Oxford University Press, Delhi, 1994) 4 (n 4).

117 Fanon, above n 14, 8.

119 See Gibson, Rethinking Fanon: the Continuing Dialogue, above n 111. 
related discourses such as 'Critical Race Feminism'. ${ }^{120}$ His portrayal of the symbols of imperial representation, ${ }^{121}$ and the heterogeneous sites of ideological domination and resistance, also continues to influence some of the major subject areas in contemporary postcolonial discourse.

There have been a number of critical theories which have emerged since the time of Fanon's writing, and not surprisingly, several critiques have developed on his work by contemporary scholars. For example, with the use of a poststructuralist framework, Homi Bhabha suggests that Fanon's division between "Black skins, white masks" is not ... a neat division'. ${ }^{122}$ Rather, 'it is a doubling, dissembling image of being in at least two places at once'. ${ }^{123}$ Similarly, adopting a feminist critique (and also the benefit of another retrospective lens), Ania Loomba argues that Fanon's subject is 'resolutely male, and reinforces existing gender hierarchies even as it challenges racial ones. ${ }^{124}$ Nevertheless, Frantz Fanon remains a leading figure in postcolonial discourse, and his foundational work in this area continues to impact significantly upon some of the critical themes in contemporary postcolonial scholarship.

\section{B. Homi Bhabha and the Concept of Hybridity}

A central theme in contemporary postcolonial discourse is the issue of 'hybridity' - the cross-fertilisation of identities and ideas as a result of colonialism. ${ }^{125}$ While

120 On this point, Gibson states ' $[\mathrm{t}]$ hat Fanon is engrossing to critics on both sides of the postmodernist/ modernist divide; that he is claimed by Afrocentrists and Marxists; that he is engaged by feminists and postcolonial literary critics; that he is the object of such varied appreciations as well as misconceptions is itself an accomplishment. Fanon's thought continues to be reconsidered, not only because it cannot be fully claimed by one disciplinary framework and is open to reinterpretation and reconstruction but also because it remains vital': Nigel Gibson, 'Introduction' in Gibson (ed) Rethinking Fanon: the Continuing Dialogue (1999) 9-46, 38-9, 43.

For example, the colonial world is a 'world of statues: the statue of the general who carried out the conquest, the statue of the engineer who built the bridge'. Significantly, the 'first thing which the native learns is to stay in his place, and not to go beyond certain limits': Fanon, The Wretched of the Earth, above n 72, 51-2.

Homi K Bhabha, 'Remembering Fanon: Self, Psyche and the Colonial Condition' in Chrisman and Williams (eds), Colonial Discourse and Post-colonial Theory: a Reader (1994) 112-23, 117. Ibid.

124 Ania Loomba, Colonialism/Postcolonialism (1998) 148; see also 162-3. See also Gwen Bergner, 'Who is that Masked Woman? or, The Role of Gender in Fanon's Black Skin, White Masks' (1995) 110 Publications of the Modern Language Association of America 75.

Young suggests that '[a] hybrid is a cross between two species'. The term 'hybridisation' refers to both the cross-breeding of species, and also 'the vocabulary of the Victorian extreme right' which regarded different races as different species. See Robert JC Young, Colonial Desire: Hybridity in Theory, Culture and Race 
there is considerable dispute as to the precise definition and meaning of the term, ${ }^{126}$ in postcolonial theory 'hybridity' generally refers to the ambivalent in-between space created by the interaction of the colonisers and the colonised. ${ }^{127}$

The concept of 'hybridity' in postcolonial theory is perhaps most closely associated with the work of Homi Bhabha. ${ }^{128}$ Bhabha draws on the work of Fanon, and psychoanalytical theory, to explain the impact colonial discourses continue to have on both the colonised and the colonisers. ${ }^{129}$ In Black Skin, White Masks, Fanon asserted that the colonised subject experiences dehumanisation and psychic trauma upon realising that despite the use of 'white masks', 'he' ${ }^{130}$ will never be able to attain the whiteness that he has been conditioned to desire. Bhabha elaborates on Fanon's thesis, and suggests that colonial discourses cannot simply be explained in terms of two distinct spheres: the 'mother culture' and 'alien cultures'. ${ }^{131}$ Instead, colonialism produces a 'hybridity': fluctuating identities which are not stable or single, but rather, are caught within the oppositional space between the colonising and colonised cultures. ${ }^{132}$ Moreover, the place of Otherness and difference is never entirely oppositional: the 'contour of difference' is always 'agonistic, shifting, [and]

(1995) 8, 10. For a useful summary of various historical positions on hybridity, see Young at 18.

Indeed, other terms have also been used in postcolonial theory to describe the processes of hybridity, such as 'creolization'. Ashcroft et al define 'creolization' as ' $[\mathrm{t}]$ he process of intermixing and cultural change that produces a creole society. While the creolization processes might be argued to be going on throughout the world, the term has usually been applied to 'new world' societies (particularly the Caribbean and South America) and more loosely to those post-colonial societies whose present ethnically or racially mixed populations are a product of European colonization': See Ashcroft, Griffiths and Tiffin, Post-Colonial Studies: the Key Concepts, above n 28, 57-9.

For a clear overview of the concept of hybridity in postcolonial theory, see Loomba, above n 121, 173-83.

For a collection of Bhabha's essays, see Homi K Bhabha, The Location of Culture (1994).

129 See Bhabha, above n 122.

130 The pronoun 'he' is used, as it seems clear from reading Fanon's texts that his 'subject' is male.

131 Homi K Bhabha, 'Signs Taken for Wonders' in Ashcroft, Griffiths and Tiffin (eds), The Post-Colonial Studies Reader (1995) 29-35, 34.

132 For example, in one of Bhabha's most influential essays, 'Signs Taken for Wonders', he describes how the Bible becomes hybridised in the process of communicating 'the message' to the Other. Bhabha concludes that 'the colonial presence is always ambivalent, split between its appearance as original and authoritative and its articulation as repetition and difference'. However, despite the 'imitation' and 'mimicry' between the colonised and colonisers, the relationship is one of conflict. Ultimately, Bhabha suggests that hybridity may be the most effective form of subversive opposition, as it illustrates the 'necessary deformation and displacement of all sites of discrimination and domination': See ibid 32, 34. 
splitting'. ${ }^{133}$ According to Bhabha, '[i]t is always in relation to the place of the Other that colonial desire is articulated: that is, in part, the fantasmatic space of 'possession' that no one subject can singly occupy which permits the dream of the inversion of roles. ${ }^{134}$

Significantly, Bhabha suggests that the notion of 'hybridity' not only affects the colonised, but also the colonisers, who must constantly re-define and re-invent themselves in relation to the Other. ${ }^{135}$ In fact, the colonisers undermined their own authority by not being able to mimic or replicate their own selves perfectly. ${ }^{136}$ Thus, both the colonised and the colonisers are dependent on each other for their various, unstable, shifting identities. Bhabha draws on his theories of hybridity to criticise the static portrayal of colonialism evident in Edward Said's Orientalism (discussed below), in which 'colonial power and discourse is possessed entirely by the colonizer', privileging the fixed colonial view. ${ }^{137}$

For Bhabha, the ambivalence in the colonial presence suggests a failure for colonial discourse, and marks the site for resistance and subversion:

Resistance is not necessarily an oppositional act of political intention, nor is it the simple negation or exclusion of the 'content' of another culture ... It is the effect of an ambivalence produced within the rules of recognition of dominating discourses as they articulate the signs of cultural difference. ${ }^{138}$

Bhabha suggests that the exploitation of this hybrid and ambivalent state can lead to subversion, and the construction of new anti-essentialist (postmodern?) identities. ${ }^{139}$ Indeed, given its poststructuralist and postmodernist lineage, contemporary postcolonial scholarship (and also critical legal theory) tends to prefer counterhegemonic anti-colonialisms which subvert, rather than simply reverse, the binary oppositions of colonial discourse. In effect, Bhabha's dislocated and dispersed

Ibid 32.

Bhabha, above $\mathrm{n} 122$.

According to Bhabha, national identity is at least partly constructed through the existence of the outsider, as it is against the Other by which 'the nation' is defined. Moreover, the cultural parameters of the nation 'contain' sources of meaning which are produced through the processes of hybridity, and where the shifting identity of the nation is made (and re-made) by assimilating new groups, and constructing new sites of antagonism. See 'DissemiNation: Time, Narrative and the Margins of the Modern Nation', in Bhabha, above n 128, 139-70.

For further discussion see Young, above n 6, 68-9.

Homi K Bhabha, 'The Other Question: Difference, Discrimination and the Discourse of Colonialism' in Barker et al (eds), Literature, Politics and Theory (1986) 148-72, 158.

Bhabha, above n 131, 33 .

For an interesting discussion of Bhabha's views, see Michael Hardt and Antonio Negri, Empire (2000) 143-6. 
subject successfully violates the established colonial ideological and epistemological norms.

While there have been several criticisms of both Bhabha's work, ${ }^{140}$ and also the concept of hybridity, ${ }^{141}$ the hybrid world view offers powerful new ways of approaching complex issues in law, such as cultural identity. Significantly, the concept of hybridity in Bhabha's work not only subverts the traditional Western oppositional dualisms (for example, subject/object, man/woman, white/black), it also cautions against the interpretation of cultural identities in essentialist or reductive terms. This is important, as universal accounts of society and culture have proven to be exclusionary, as they are only ever achieved through the suppression of alternative specificities.

The notion of hybridity is a useful theoretical tool for legal discourse, as it enables new ways of thinking about the law, legal identities, and legal cultures. This may be particularly important for the liberal view of law, as it continues to be structured around fairly monochromatic views of culture and identity. By promoting the merits of deconstructing legal discourse within its wider context, a hybrid world view encourages a broader understanding of the idea of law, and this will (hopefully) prompt a different reading of it.

\section{Gayatri Chakravorty Spivak and the Question of the Subaltern}

The question of 'the subaltern' is at the heart of contemporary debates in postcolonial discourse. ${ }^{142}$ The term 'subaltern' in postcolonial theory is generally

140 For example, Bhabha has been criticised for not questioning the Eurocentric base of the Freudian and Lacanian psychoanalyical methods he uses to diagnose the colonial condition. See Ato Quayson, Postcolonialism: Theory, Practice, or Process? (2000) 42-3. See also Ashcroft, Griffiths and Tiffin, The Post-Colonial Studies Reader, above $\mathrm{n}$ 9, 9. Loomba suggests that despite Bhabha's emphasis on hybridity, he ironically universalises the colonial condition and presents the homogenous 'hybrid colonial subject'. His subject is also obviously male: See Loomba, above n 124, 178. For example, Benita Parry suggests that the concept of hybridity distorts the dynamics of anti-colonial struggles, and the antagonistic relationship between the colonisers and the colonised. See Benita Parry, 'Problems in Current Theories of Colonial Discourse' in Ashcroft, Griffiths and Tiffin (eds), The Post-Colonial Studies Reader (1995) 36-44, 42-3. For Parry, the anti-colonial counter-narratives were important, as they challenged and undermined 'the ruling ideologies ... nowhere more so than in overthrowing the hierarchy of coloniser/colonised': See Benita Parry, 'Resistance Theory/ Theorising Resistance, or Two Cheers for Nativism' in Barker, Hulme and Iversen (eds), Colonial Discoursel Postcolonial Theory (1994) 172-96, 176.

The word 'subaltern' is heavily associated with the work of Antonio Gramsci in postcolonial theory. Gramsci used the term 'subaltern' to refer to the historically 'inferior' classes, and argued that the essence of the historical is the varied interplay between the hegemonic class and the subaltern: See Antonio Gramsci, Selections 
used to refer to the various hierarchies which existed within the colonised world that is within the 'native' population. The central argument made by subaltern theorists is that there was never simply $a$ subject/subordinate/subaltern position, but several, and a multiplicity of hierarchies existed within the colonised (and also colonising) groups.

As the colonial narrative of domination and resistance was largely told by those with the power to speak, subaltern scholarship is concerned with issues relating to agency, and the importance of the subaltern presence in interrogating the dominant account. Scholars interested in representing the subaltern view employ the term to re-write a history that seeks to describe the contribution made by the subaltern on their own (that is independently of the elite - either local or foreign). ${ }^{143}$

The theoretical trajectory of subaltern studies is broad. According to Gyan Prakash, '[s]ubaltern [s]tudies obtains its force as postcolonial criticism from a catachrestic combination of Marxism, poststructuralism, Gramsci and Foucault, the modern West and India, archival research and textual criticism. ${ }^{144}$ All of these theoretical approaches are evident in the work of Gayatri Spivak, who has focused extensively on the question of the subaltern. ${ }^{145}$ As one of the leading scholars in postcolonial

from Political Writings, 1921-1926 (1978). For a survey of subaltern studies scholarship, see Ranajit Guha and Gayatri Chakravorty Spivak (eds), Selected Subaltern Studies (1988); Vinayak Chaturvedi, Mapping Subaltern Studies and the Postcolonial (2000); Walter D Mignolo, Local Histories/Global Designs: Coloniality, Subaltern Knowledges, and Border Thinking (2000); Gyan Prakash, 'Subaltern Studies as Postcolonial Criticism' (1994) 99 American Historical Review 1475. Legal scholars have also engaged with subaltern studies scholarship. See, eg, BS Chimni, 'Alternative Visions of Just World Order: Six Tales From India' (2005) 46 Harvard International Law Journal 389, 395-6; Otto, above n 70.

For example, Guha and Spivak's edited work demonstrates that in the context of Indian colonial history, this means articulating the suppressed accounts of the mass of subaltern Indians (for example, the peasants, women, and urban poor) who resisted British rule in very different forms to the Indian elite: See Spivak and Guha, above $\mathrm{n}$ 104. See also Shahid Amin, Event, Metaphor, Memory: Chauri Chaura 1922-1992 (1995); Kancha Ilaiah, Why I am not a Hindu: a Sudra Critique of Hindutva Philosophy, Culture and Political Economy (1996). Prakash, above n 142, 1490.

145 Spivak's work was first internationally acknowledged after her celebrated translation of Derrida's classic deconstructivist text Of Grammatology (1976). She has subsequently applied deconstructive analyses to various theoretical engagements, such as feminism, Marxism, literary criticism, and postcolonial theory. The Derridean deconstructivist mode displaces and reverses an opposition. This is turn provides a platform for effecting 'critical leverage', and enables the critic to place herself or himself in an ambivalent relation to the theoretical method being employed, and also synchronously disorients the audience from the familiarity of the politico-theoretical structures which it seems to take for granted. Spivak argues that this process makes it at least partially possible to critique dominant systems, without simply becoming entangled within the exercise. However, she warns that such a 
theory, Spivak expresses her discomfort with the difficulties and contradictions inherent in constructing a 'subaltern voice'. In particular, she is concerned about the pitfalls of essentialism, and the dangers inherent in constructing another monolithic category - that is 'the subaltern voice'. ${ }^{146}$ For Spivak, while it is important not to be 'rhetorically committed' to totalising schemas such as essentialism, strategically this is a near impossibility, because even when 'we talk about feminist practice, or privileging practice over theory, we are universalising — not only generalising but universalising. ${ }^{147}$ For this reason, she advocates a pragmatic approach, where the critic is forced to admit that they 'are an essentialist from time to time. ${ }^{148}$ The alternative for Spivak is 'theoretical purity', where 'the great custodians of the antiuniversal ... keep themselves clean by not committing themselves to anything. ${ }^{149}$

The location of the subaltern in discourse raises several significant questions, such as: Can the subaltern speak? To what extent did colonialism silence the subaltern voice? Is the position of the subaltern necessarily subordinate? If the subaltern can speak, do they use their own 'authentic' voice, or that of their colonial masters? ${ }^{150}$ If the subaltern cannot speak, who can write as Other, and represent the subaltern voice (for example, intellectuals, members of the imperial classes, the former colonial masters)? ${ }^{151}$ All of these questions are explored by Spivak in a highly

displacement can only be produced 'by taking the investigator's own complicity into account', as the critic herself is not free from cultural and historical conditionings: See Gayatri Chakravorty Spivak, 'The Rani of Sirmur' in Barker et al (eds), Europe and its Others: Proceedings of the Essex Conference on the Sociology of Literature July 1984, Volume 1 (1985) 128-51, 147. Spivak's writings include: Gayatri Chakravorty Spivak, Outside in the Teaching Machine (1993); Gayatri Chakravorty Spivak, A Critique of Postcolonial Reason: Toward a History of the Vanishing Present (1999); Gayatri Chakravorty Spivak, 'Can the Subaltern Speak?' in Nelson and Grossberg (eds), Marxism and the Interpretation of Culture (1988) 271-313; Gayatri Chakravorty Spivak, In Other Worlds: Essays in Cultural Politics (1987); Gayatri Chakravorty Spivak, The Post-colonial Critic: Interviews, Strategies, Dialogues (1990); Gayatri Chakravorty Spivak, Death of a Discipline (2003); Gayatri Chakravorty Spivak, Thinking Academic Freedom in Gendered Post-coloniality (1992).

On this point, O'Hanlon suggests that subaltern historians documenting the differences between Indian peasant and elite anti-colonial struggles continue to construct an essential monolithic peasant identity: See Rosalind O'Hanlon, 'Recovering the Subject Subaltern Studies and Histories of Resistance in Colonial South Asia' (1988) 22 Modern Asian Studies 189, 201-2. Spivak, The Post-colonial Critic: Interviews, Strategies, Dialogues, above n 145, 11. Ibid 12.

Ibid.

The concept of 'authenticity', or what is considered to be 'authentic' is highly problematic: See, eg, Gareth Griffiths, 'The Myth of Authenticity' in Ashcroft, Griffiths and Tiffin (eds), The Post-Colonial Studies Reader (1995) 237-41. 
influential essay titled 'Can the Subaltern Speak?' ${ }^{152}$ She uses the word to refer to the oppressed subject, and argues that ultimately, it is impossible for the subaltern to speak. In her paper, Spivak focuses on the issue of widow immolation (or sati) in colonial India, ${ }^{153}$ and suggests that both colonialism and patriarchy operate not as separate, but two mutually supporting systems of domination that intersect in the lives of the subaltern sexed subject, or 'the brown woman'. ${ }^{154}$ The effect is multiple

'the limited proposition that only a black can write about blacks, a Muslim about Muslims, and so forth': See Said, above n 25, 322. See Spivak, 'Can the Subaltern Speak?', above n 145.

On the practice of sati (ie widow immolation, where widowed women were expected to join their dead husbands on the funeral pyre), see further Lata Mani, 'Contentious Traditions: the Debate on Sati in Colonial India' in Sangari and Vaid (eds), Recasting Women (Rutgers University Press, New Brunswick, 1989) 88-126; Lata Mani, 'Cultural Theory, Colonial Texts: Reading Eyewitness Accounts of Widow Burning' in Grossberg, Nelson and Treichler (eds), Cultural Studies (1992) 392-408.

Spivak has written extensively on the topic of what she calls the 'subaltern woman'. For example, in her essay 'French Feminism in an International Frame', Spivak illustrates the narcissism inherent in Julia Kristeva's text About Chinese Women (1977). This text emerged as part of the academic French interest in China during the 1970s. Spivak argues that Kristeva merely presents her mute native material, as the reader can never actually hear the object of Kristeva's investigation (ie the Chinese women) represent themselves. Moreover, Spivak asserts that Kristeva generalises in her investigations on China 'with no encroachment of archival evidence'. She focuses on Kristeva's privileged position as an investigator (and authoritative knower), and suggests that this act of authoritarian knowing or 'epistemic violence' results in Kristeva's text being more 'about her own identity rather than theirs'. Thus, in the process of representing her Other, the liberal feminist (in this case Kristeva) silences the 'native woman'. Spivak places Kristeva in 'the group of thinkers' who in 'spite of their occasional interest in touching the other of the West, of metaphysics, of capitalism, their repeated question is obsessively self-centred: if we are not what official history and philosophy say we are, who then are we (not), how are we (not)?': See 'French Feminism in an International Frame' in Spivak, In Other Worlds: Essays in Cultural Politics, above n 142, 134-53, especially 137. Spivak's arguments with respect to the 'gendered subaltern' are also repeated in her other works. In her highly influential essay discussed above, 'Can the Subaltern Speak?', Spivak argues that the gendered subaltern 'disappears, not into a pristine nothingness, but into a violent shuttling which is the displaced figuration of the "third-world woman" caught between tradition and modernization.' She suggests that the gendered subaltern 'disappears', as she is never heard speaking for herself, or about herself. She is merely a medium through which competing discourses assert their respective claims. See Spivak, 'Can the Subaltern Speak?' above n 142, 306. There has also been extensive debate in feminist legal theory on the issue of the 'coloured woman', or the subaltern woman. Highly influential earlier works include Angela Harris, 'Race and Essentialism in Feminist Legal Theory' (1990) 42 Stanford Law Review 581; M Kline, 'Race, Racism, and Feminist Legal Theory' (1989) 12 Harvard Women's Law Journal 115; M Mahoney, 'Whiteness and Women, In Practice and Theory: a Reply to Catherine MacKinnon' (1993) 5 Yale Journal of Law and Feminism 217. 
subordination, making it extremely difficult for the subaltern to speak (even though elite brown men may have found a voice as they were further up in the colonial hierarchy). For this reason, Spivak argues that postcolonial intellectuals must 'represent' the subaltern, as '[t]he subaltern cannot speak., 155

Given the complexities involved in locating subaltern voices, Lata Mani suggests that the question 'Can the Subaltern Speak?' may be more clearly rephrased as 'a series of questions', such as: 'Which groups constitute the subalterns in any text? What is their relationship to each other? How can they be heard to be speaking or not speaking in a given set of materials? With what effects?' ${ }^{156}$ There have of course been several criticisms of Spivak's work. ${ }^{157}$ Nevertheless, her analysis of the subaltern subject, and in particular, her thesis on essentialist positions, has been profoundly influential in contemporary postcolonial discourse.

A common objection to subaltern studies is that its very fragmentary nature makes it impossible to construct any kind of sophisticated understanding of how dynamic hierarchies intersect and operate in relation to each other. However, while subaltern scholarship has clearly encouraged movement away from grand narratives and theorising, and the construction of essential identities, subaltern accounts do not necessarily result in the disappearance of universal stories. Rather, they force totalising discourses to be read in a different manner. Moreover, the subaltern project makes it possible to begin at least to recover some of the voices of the Other, which have effectively been silenced by Western discourses. Indeed, the subaltern account forces a different world view from the one portrayed by the omnipresent Western canonical knowledge systems, and also serves as a useful reminder of the pitfalls of any kind of universalising. For this reason, it is a powerful theoretical tool for any discourse — including the law.

\section{Edward Said's 'Orientalism'}

In his enormously influential text, Orientalism: Western Conceptions of the Orient (1978), Edward Said combines the theoretical traditions of Marxism and

\footnotetext{
155 Spivak, 'Can the Subaltern Speak?', above n 145, 308.

156 Mani, 'Cultural Theory, Colonial Texts: Reading Eyewitness Accounts of Widow Burning', above n 153, 403.

157 For example, some critics suggest that Spivak's position on subaltern silence is problematic because of its negativity, and its complete acceptance of the ideological hegemony of the dominant discourse. For example, Benita Parry suggests that Spivak's analysis of Jean Rhys's novel Wide Sargasso Sea (1968) fails to depict any evidence of female agency in Caribbean cultures and, in fact, is deliberately deaf even when the native voice can be heard: See Parry, 'Problems in Current Theories of Colonial Discourse', above n 141, 38-40. Ashcroft et al also suggest that Spivak's theoretical approach (like Bhabha's) has been criticised for being 'too deeply implicated in European intellectual traditions': See Ashcroft, Griffiths and Tiffin, The Post-Colonial Studies Reader, above n 9, 9.
} 
poststructuralism to produce a profound understanding of the construction of the Other, and the contiguous relationship which exists between Western knowledge systems and colonial power. ${ }^{158}$ Orientalism's revolutionary impact on intellectual thought, both in the West and non-West, testifies to its status as the founding text in postcolonial studies. ${ }^{159}$ Indeed, Said's concept of the Other in Orientalism constitutes the very heart of postcolonial theory.

The major argument in Said's deeply provocative work is that Western knowledge of the Orient is inextricably linked to Western power over the Orient, as knowledge and power are thoroughly homologous, dialogical, and reciprocal in their processes and effects. Rather than focus on the history of anti-colonial struggles, Said explores the ways in which the 'Orient' as an idea was constructed and created in European minds. Said traces the discursive and textual constructions of Western 'truths' about the Other, in order to illustrate how these 'truths' concomitantly consolidate Western political hegemony and Western cultural power. Significantly, Said illustrates that the West is also a construct, and the colonised Orient also 'helped to define Europe (or the West) as its contrasting image, idea, personality, experience. ${ }^{160}$ Moreover, Said resists the conclusion that there was 'a real or true Orient' that was different from the Orientalist constructions of the Other. ${ }^{161}$ By exploring the ideological disguises of the colonial and imperial process, Said in Orientalism traces the reciprocal relationship between knowledge and power. For Said, 'Orientalism' (or the academic study of the Orient), has been an essential accessory to Europe's domination and authority over the Other. Said subsequently

Said, above $\mathrm{n} 25$.

To illustrate, the editors of the influential Essex symposia series on the sociology of literature have claimed that ' $[\mathrm{t}]$ here is little doubt that matters of colony and empire have moved centre stage in Anglo-American literary and cultural theory', and 'the catalyst for much of the new work' and 'an indispensable reference point' is Said's Orientalism: Francis Barker, Peter Hulme and Margaret Iversen (eds), Colonial Discourse/ Postcolonial Theory (1994) 1. Chatterjee has written passionately about his first encounter with the text: 'I will long remember the day I read Orientalism ... a book which talked of things I felt I had known all along but had never found the language to formulate with clarity. Like many great books, it seemed to say for the first time what one had always wanted to say.' Partha Chatterjee, 'Their Own Words? An Essay for Edward Said' in Sprinker (ed) Edward Said: a Critical Reader (1992) 194-220, 194. See also Spivak, Outside in the Teaching Machine, above n 142, 56. For an insight of the impact made by Orientalism from the perspective of three Indian academics teaching English literature at Delhi University, see Zakia Pathak, Saswati Sengupta and Sharmila Purkayastha, 'The Prisonhouse of Orientalism' (1991) 5 Textual Practice 195. 
argued in later works that the hegemony of the West has persisted in this postcolonial age, largely due to the continual construction of the Orient as Other. ${ }^{162}$

A reading of Orientalism reveals that its textual construction has clearly been influenced by several theoretical and philosophical traditions. In particular, Said engages in Marxist and poststructuralist theory to demonstrate the complicity of Western knowledges, and the operative interests of Western power. The use by Said of Marxism and poststructuralism is particularly interesting, as there is a longstanding debate in academia regarding the compatibility of these two distinct (and perhaps even contradictory) theoretical practices. ${ }^{163}$ Nevertheless, the seemingly impossible collusion of poststructuralist discourse and Marxist historicism is used by Said to demonstrate powerfully how the Orient was (is) constructed by the West as Other. ${ }^{164}$

As noted above, a major theme in Said's work, which is particularly evident in Orientalism, The Question of Palestine, ${ }^{165}$ and Covering Islam, ${ }^{166}$ is the collusion

Said argues that this is particularly prevalent in the Western media. See Edward W Said, Culture \& Imperialism (Vintage, London, 1993). Rosalind O'Hanlon and David Washbrook, 'After Orientalism: Culture, Criticism, and Politics in the Third World' (1992) 34(1) Comparative Studies in Society and History 141, 155-158. But see Gyan Prakash, 'Can the "Subaltern" Ride? A Reply to O'Hanlon and Washbrook' (1992) 34(1) Comparative Studies in Society and History $168,179-180$.

Although Said extensively engages in Marxist discourse, it should be noted that he is critical of the epistemological and ontological inadequacy of orthodox Marxist theory. Said's discomfort with Marxist theory lies in its failure to accommodate adequately the specific experiences of the colonised world. For example, in reference to the Palestinian question, Said asserts that 'the development of a theoretical Marxism in the Arab world did not seem to meet adequately the challenges of imperialism, the formation of a nationalist elite, the failure of the nationalist revolution, etc': See Jennifer Wicke and Michael Sprinker, 'Interview with Edward Said' in Sprinker (ed) Edward Said: a Critical Reader (1992) 221-64, 261. In terms of Marx himself, Said is critical of the ethnocentric foundations of his writing. To illustrate, Marx asserted that the British have 'a double mission in India: one destructive, the other regenerating — the annihilation of the Asiatic society, and the laying of the material foundations of Western society in Asia': Karl Marx, Surveys from Exile (1973) 320, cited in Said, above n 25, 154. It is now well-known that a capitalist society was the prerequisite social condition for Marx's revolution. For this reason, Marx defended European colonialism as a necessary historical project. Moreover, according to Marxist theory, colonialism would eventually facilitate global modes of capitalist production, which would concomitantly destroy 'backward' or pre-capitalist forms of social organisation. Thus, implicit in Marx's reasoning is the necessary and progressive role of the civilising mission of colonialism. 
between knowledge and power. Said explores Foucault's complex matrix of knowledge and power and applies it to the colonial canvas. The Foucaultian explanation of the complicity between knowledge and power is now well known. ${ }^{167}$ Foucault explored the relationship between these two concepts to illustrate how knowledge transforms power, shifting it from its concentration in monolithic entities, such as 'the State', into dispersed web-like forces encountered in everyday experiences. ${ }^{168}$

In Orientalism, Said exploits Foucault's understanding of knowledge and power, and uses his theories to focus more directly on how knowledge is transformed through the corruption of power. For Said, one of the instances when knowledge becomes contaminated is when it becomes institutionalised, and operates in the interests of a dominant elite. Said's quintessential example of the corruption and institutionalisation of knowledge for the benefit of a hegemonic group is, of course, the 'Orientalist project'. Although Said attaches several different (but interdependent) meanings to the idea of 'Orientalism', ${ }^{169}$ his principal explanation (which incorporates all his meanings) is that of a discourse in the Foucaultian sense of the term. Said contends that "without examining Orientalism as a discourse one cannot possibly understand the enormously systematic discipline by which European culture was able to manage — and even produce — the Orient politically, sociologically, militarily, ideologically, scientifically, and imaginatively'.170 Foucaultian notions of discourse are always linked to power, and exercises of power. In this way, discourses are systems of meaning, which incorporate, and are committed to the continuation of, dominant social systems. Said argues that as part of the dominant social system, the discourse of 'Orientalism' was so 'authoritative' that 'no one writing, thinking, or acting on the Orient could do so without taking account of the limitations on thought and action imposed by Orientalism.' 171

Discourses also control both the mode and the means of representation. In the context of Orientalist discourse, this meant (means) representing the Orient, because of its obvious inability to represent itself. In the process of representing the Orient as Other, negative stereotypes were (are) systematically produced (such as the terrorist, the savage, anarchy and lawlessness, poverty and general 'doom and

166 Edward W Said, Covering Islam: How the Media and the Experts Determine How We See the Rest of the World (1981).

167 See Foucault, above n 6. See further Foucault, above n 70; Michel Foucault, Language, Counter-Memory, Practice: Selected Essays and Interviews (1977). In her explanation of this concept, Sneja Gunew suggests that '[p]ower is reproduced in discursive networks at every point where someone who "knows" is instructing someone who doesn't know.' Sneja Gunew, 'Feminist Knowledge: Critique and Construct' in Gunew (ed), Feminist Knowledge: Critique and Construct (1990) 13$35,22$.

Ibid 3.

171 Ibid. 
gloom', and so on). By the continual perpetuation of these negative stereotypes, 'European culture gained in strength and identity by setting itself off against the Orient as a sort of surrogate and even underground self. ${ }^{, 172}$ These stereotypes also produced an image of 'a subject race, dominated by a race that knows them and what is good for them better than they could possibly know themselves. ${ }^{173}$ Thus, the necessity of colonial and imperial rule was (is) perpetually re-confirmed. In the words of Said in a later text, Culture and Imperialism:

Neither imperialism nor colonialism is a simple act of accumulation and acquisition. Both are supported and perhaps even impelled by impressive ideological formations which include notions that certain territories and people require and beseech domination, as well as forms of knowledge affiliated with that domination ${ }^{174}$

Said's major project of using knowledge as a vehicle for ideological and social change has subsequently been hailed by other theorists as one of postcolonial theory's key aims. As Young suggests, despite postcolonial theory's conceptual fluidity, the major project of the discourse remains coherent: first, investigating the extent to which European history, culture, and knowledge were part of the practice of colonisation, and its continuing aftermath; second, identifying and analysing the causes and effects of continuing international exploitation; and third, transforming those epistemologies into new forms of cultural and political production, and enabling the transformation of global material injustice for disempowered peoples. ${ }^{175}$

There have of course been several criticisms of Said's study in Orientalism. ${ }^{176}$ Nevertheless, due to its revolutionary impact on intellectual and cultural thought, Orientalism remains the foundational text in postcolonial studies.

Ibid.

Ibid 35 .

Said, above n 162, 8 (his emphasis).

Young, above n 6, 69.

For example, Said's text has been criticised for ironically essentialising the discourses of colonialism and imperialism, and for universalising the negative Orientalist stereotype. In the process of his textual construction, another stereotype has inadvertently been produced: the ethnocentric Occidental. Thus, the possibility of difference within Orientalist discourse is effectively silenced. Theorists such as Bhabha argue that cultural stereotypes are far more ambivalent, unstable, and dynamic than those portrayed in Said's text. For Bhabha, Orientalism 'loses some of its interrogative power' because of 'Said's inadequate engagement with alterity and ambivalence' within Orientalist discourse: See Bhabha, above n 134, 157. There is also a growing awareness, particularly amongst historical scholars, of the subversive political uses of Orientalist discourse by the colonised. Indeed, Orientalist discourses were not only strategically available for the empire, they were also available for its adversaries. Richard Fox argues that Mahatma Gandhi used positive Orientalist 


\section{POSTCOLONIAL INTERVENTIONS INTO CONTEMPORARY LAW: THE LAW REFORM COMMISSION OF WESTERN AUSTRALIA'S FINAL REPORT ON ABORIGINAL CUSTOMARY LAWS}

There has recently been focus on the Indigenous Other, and the hybrid condition created by colonialism, with the renewed discussion on the recognition of Aboriginal customary laws in Australia. In September 2006, the Law Reform Commission of Western Australia (LRCWA) published its final report on the recognition of Aboriginal customary laws, which was the culmination of six years of research and wide-ranging consultations with Aboriginal and non-Aboriginal peoples, organisations, and government agencies in Western Australia. ${ }^{177}$ The Report follows the extensive study by the Australian Law Reform Commission (ALRC) in 1986, ${ }^{178}$ and more recently, the Law Reform Committee of the Northern Territory (NTLRC) in $2003^{179}$ on the recognition of Aboriginal customary laws. The ALRC Report was based on wide-ranging consultations with Aboriginal and non-Aboriginal people, and applied a flexible (or 'functional') approach towards the recognition of Aboriginal customary law in five areas: marriage, children and family property; the criminal law and sentencing; problems of evidence and procedure; local justice mechanisms for Aboriginal communities; and hunting, fishing and gathering rights. ${ }^{180}$ The NTLRC Report also adopted a flexible approach towards the recognition of Aboriginal customary laws in specific areas in the Northern Territory, and makes a total of 12 recommendations - ranging from a recognition of Aboriginal law as a source of law in the Northern Territory (Recommendation 11), to establishing an inquiry into the issue of payback (Recommendation 6). ${ }^{181}$

In his discussion on Islamic law and English texts, John Strawson explains that 'legal Orientalism' was the process whereby ' $[\mathrm{t}]$ he overriding aim was to make Islamic law understandable to the English lawyer or official. ${ }^{182}$ In a similar vein,

images of India to construct an 'authentic' pre-colonial cultural identity in opposition to Western civilisation and British colonial rule. Indeed, Gandhi 'depended on an Orientalist image of India as inherently spiritual, consensual, and corporate.' Moreover, the positive stereotype of the spiritual 'East' provided an alternative to the capitalist and exploitative 'West': See Richard Fox, 'East of Said' in Sprinker (ed) Edward Said: a Critical Reader (1992) 144-56, 151.

Law Reform Commission of Western Australia, Aboriginal Customary Laws Final Report (No 94) (LRCWA, Perth, 2006). The Report is available online:

$<\mathrm{http}: / /$ www.lrc.justice.wa.gov.au/> at 12 April 2007. See ALRC, above n 61.

See Northern Territory Law Reform Committee, Report on Aboriginal Customary Law (NTLRC, Darwin, 2003). The Report is available online:

$<$ http://www.nt.gov.au/justice/docs/lawmake/ntlrc_final_report.pdf $>$ at 12 April 2007. Ibid.

181 See above n 178.

182 John Strawson, 'Islamic Law and English Texts' (1995) 6 Law and Critique 21, 22. 
Spivak suggests that by codifying Hindu law, the British in colonial India reduced a 'polymorphous structure' to a far more clearly organised system — which was essentially comprehensible to the coloniser. ${ }^{183}$ According to Spivak, 'in the constitution of that Other of Europe, great care was taken to obliterate the textual ingredients with which such a subject could cathect, could occupy (invest?) its itinerary - not only by ideological and scientific production, but also by the institution of the law. ${ }^{, 184}$ While on one level, all three Reports into the recognition of Aboriginal customary laws can certainly be viewed as an exercise in 'legal Orientalism' (with Western legal discourse continuing its conversation (with itself) to explain the Other), the Reports also, importantly, exploit the 'hybrid' in-between space created by colonialism, where the Indigenous subaltern is finally offered a platform to speak about their laws. The LRCWA Report into the recognition of Aboriginal customary laws in WA will be considered in further detail below.

The LRCWA Report contains a total of 131 recommendations, and focuses not only on legislative amendment, but also on reform in government procedures and policies relating to Aboriginal people. In December 2005, the LRCWA also published an extensive Discussion Paper which made 93 proposals for law reform in Western Australia that would lead to the recognition of Aboriginal customary laws, and at the same time address the several areas of Indigenous disadvantage in Western Australia. ${ }^{185}$ The Final Report is intended to be read in conjunction with the LRCWA's earlier Discussion Paper, as the Paper provides greater detail and analysis with respect to the Commission's initial findings.

The final Report is divided into 10 chapters, with the first four chapters addressing general issues surrounding the recognition of customary law: Chapter One focuses on the misconceptions about Aboriginal customary law, particularly those that appeared in the media following the publication of the Discussion Paper; Chapter Two outlines some of the guiding principles for reform; Chapter Three focuses on the condition of Aboriginal disadvantage in Western Australia; and Chapter Four discusses the manner in which customary law should be recognised, and also the barriers which exist towards recognising customary law in Western Australia. The following six chapters focus on specific issues with respect to the hybrid space between Aboriginal law(s) and Western Australian law in particular areas: the lengthy Chapter Five discusses the criminal justice system; Chapter Six deals with the civil law system; Chapter Seven focuses on family law (and family violence); Chapter Eight discusses customary hunting, fishing and gathering rights; Chapter Nine deals with evidence and courtroom procedure; and Chapter Ten with Aboriginal community governance in Western Australia. For the purposes of

\footnotetext{
183 Spivak, 'Can the Subaltern Speak?', above n 145, 281.

184 Ibid 280

185 Law Reform Commission of Western Australia, Aboriginal Customary Laws Discussion Paper (LRCWA, Perth, 2005). The Discussion Paper is available online: $<$ http://www.lrc.justice.wa.gov.au/> at 12 April 2007.
} 
implementation, Appendix B to the Report also identifies the relevant government body that will be responsible for executing the 131 recommendations.

The recommendations in the LRCWA Report vary greatly in scope and subject matter. ${ }^{186}$ They range from the very important constitutional recognition of the unique status of Aboriginal peoples as the descendants of the original inhabitants of Western Australia - a recognition that would be implemented by an amendment to the Constitution Act 1889 (WA) in s 1 (Recommendation 6); to the more mundane recommendations that the Western Australia Department of Corrective Services revise its policies with respect to escorting Aboriginal prisoners and detainees to funerals (Recommendation 62), and that the customary harvesting exemption currently provided by s 23 of the Wildlife Conservation Act 1950 (WA) apply also to land designated under the Conservation and Land Management Act 1984 (WA) (Recommendation 100); to the more broad acknowledgement of the importance of recognising and protecting Indigenous cultural and intellectual property (Recommendations 80, 81 and 82). Several recommendations also focus on the need for cultural awareness training for individuals and bodies who have regular dealings with Aboriginal people. ${ }^{187}$ The LRCWA recommends the creation of an Office of the Commissioner for Indigenous Affairs, which will be responsible for a range of functions, including: reporting directly to Parliament on the implementation of the Report (and also the Report of the Royal Commission into Aboriginal Deaths in Custody (1991)); reporting on the progress in the reduction of the over-representation of Aboriginal people in the criminal justice system; monitoring and evaluating government initiatives directed towards the Indigenous community; and publishing research on issues relating to Aboriginal people in Western Australia (Recommendation 3). It should also be noted that a number of Recommendations are applicable to both Indigenous and non-Indigenous Western Australians. ${ }^{188}$

The LRCWA should be commended for making a very genuine attempt both to recognise and incorporate aspects of Aboriginal customary law into the Western Australian legal system. The Report mounts a serious challenge to some of the myths and misconceptions about Aboriginal customary law, and constructs a substantial argument, based on the formal equality versus substantive equality debate, as to why Aboriginal people should be treated differently from other Australians. ${ }^{189}$ The Report also acknowledges the position of severe disadvantage of Aboriginal people in Western Australia, and attempts to level the playing field

\footnotetext{
186 The list of Recommendations are contained in Appendix A to the Report, and may also be viewed online: $<$ http://www.lrc.justice.wa.gov.au/Aboriginal/Final $\% 20$ Report/Recommendations.pdf $>$ at 12 April 2007. See Recommendations 2, 11, 12, 56, and 128 . See Recommendations 8, 25, 27, 29, 30, 31, 33, 35, 36, 40, 42, 43, 45, 46, 47, 48, 49, $52,55,57,58,61,64,68,71,75,76,77,78,79,89,110,120,121,122,125$ and 126. See above n 177, especially Chapters One and Four.
} 
between Indigenous and non-Indigenous Western Australians in various ways. ${ }^{190}$ However, from a postcolonial point of view, the Report makes it clear that Aboriginal customary law may only be recognised if it is not inconsistent with Anglo-Australian law. To use the words of the LRCWA Report:

the Commission has proceeded from the starting point that recognition of Aboriginal customary law must work within the framework of existing Western Australian law and also be consistent with international human rights standards. In doing so the Commission acknowledges that to a certain extent the recognition of Aboriginal law must be subjugated to the dominant interests of the state and the international community. ${ }^{191}$

Thus, while on one level, the Report makes a determined and sincere effort to acknowledge and recognise Aboriginal customary law in its various postcolonial forms in contemporary Australia, this recognition is tempered by the confines of the dominant (Western) legal paradigm. In other words, Aboriginal customary law exists to the extent that we say that it exists. It is also worthwhile to note that this same principle is echoed in both the ARLC Report ${ }^{192}$ and the NTLRC Report. ${ }^{193}$

The notion that 'Aboriginal law must be subjugated to the dominant interests of the state' $^{194}$ is inherently problematic from a postcolonial stance, and has led to commentators such as Professor Chris Cunneen and Melanie Schwartz to dismiss the concept of customary law as 'imperialist', because it 'has been used to construct and delimit Indigenous law as lesser.' ${ }^{195}$ In their Background Paper to the LRCWA Report, they argue that the difficulty in this position is that:

190 For example, apart from the Recommendations already mentioned, the recognition of the different circumstances of Aboriginal people living in remote communities by extending the criteria for an extraordinary drivers licence or cancellation of a licence suspension order (Recommendations 13 and 14); the evaluation of diversionary options to ensure Aboriginal people are diverted at the same rate as non-Aboriginal people (Recommendation 51); the removal of discriminatory provisions currently governing the distribution of Aboriginal intestate estates (Recommendation 65); and improving local government accountability for expenditure of funds designated for Aboriginal people (Recommendation 129). See above n 177, 11. See above n 61, especially Ch 11 .

193 The NTRLC Report states: '[t]raditional law can be recognised by judges and government decision makers where relevant as long as it does not conflict with Australian law': see above n 175, 6. See above $\mathrm{n} 188$.

Chris Cunneen and Melanie Schwartz, 'Customary Law, Human Rights and International Law: Some Conceptual Issues', Aboriginal Customary Laws: Background Paper 11 (LRCWA, Perth, 2006) 429-50, 433. The Background Paper is available online:

$<$ http://www.lrc.justice.wa.gov.au/2publications/reports/ACL/BP/BP-11.pdf> 
the state does not approach Indigenous law on equal terms. It requires Indigenous law to meet validity thresholds that it does not require of itself, making its legality subject to consistency with the dominant system ... Thus, the colonial (and post-colonial) validation of Aboriginal law has taken place entirely subject to the criteria of the imposed legal system and in relation to it. This has occurred independent of the factual existence of Aboriginal law which, of course, does not rely on external validation for its relevance to Indigenous communities. Yet in the eyes of state law, the validity of Indigenous law has been and is dependent on recognition by the imposed law of the colonisers. ${ }^{196}$

Moreover, in the process of recognising imperialist concepts such as customary law, 'colonial power is further consolidated at the same time that it encourages Indigenous acceptance of the good faith and efficacy of colonial institutions. The discussion about recognition of customary law becomes part of the continuing story of colonisation. ${ }^{197}$ Watson also asserts that colonial powers 'examine which part of indigenous law they can splice and incorporate into the colonial system of laws and which unsavoury, uncivilised parts are best left out' ${ }^{198}$ For these reasons, Cunneen and Schwartz assert that '[a] more appropriate starting point is [the] recognition of Indigenous rights in relation to self-determination' as colonial constructs such as customary law 'will in all likelihood remain unsatisfactory to Indigenous people.' 199

The position that Aboriginal law should only be recognised to the extent that it does not conflict with Anglo-Australian law is a particularly powerful idea in which to explore the continual hegemony of Western law in this so-called postcolonial age. As a form of universality, the law mimics a particular culturally produced view about the world, and the relationship between the subject (or producer) of knowledge, and the object (or consumer). The subject's position of historical privilege ensures not only that it continues to have the power to speak, but that those different (or Other) from it eventually disappear into its oneness. As the position of the Other is assumed to be assimilable, difference is obliterated to make room for universal truths. Young and Levinas explain further:

In Western philosophy, when knowledge or theory comprehends the other, then the alterity of the latter vanishes as it becomes part of the same. This 'ontological imperialism', Levinas argues, goes back at least to Socrates but can be found as recently as Heidegger. In all cases the other is neutralized as a means of encompassing it: ontology amounts to a philosophy of power, an egotism in which the relation with the other is accomplished through its assimilation into the self. Its political implications are clear enough: 'Heidegger, with the whole of Western history, takes the relation with the

at 26 May 2007.

Ibid 432-3.

Ibid 433.

199 Cunneen and Schwartz, above n 195, 430. 
Other as enacted in the destiny of sedentary peoples, the possessors and builders of the earth. Possession is preeminently the form in which the other becomes the same, by becoming mine.' 200

Western law's ontological relation with its Other has invariably resulted in the muting of 'sedentary peoples'. It is primarily for this reason that the historically subaltern insist upon the recognition of their own voice in this postcolonial age. While the framework of the Reports ensure that the knowledge-bearers and gatekeepers remain predictably the same, the incorporation of at least some Indigenous voices into the foray will hopefully hybridise and shake-up of the same old whitefella law. Indeed, on a formal level at least, all three Reports on Aboriginal customary law stress the importance of continued Indigenous involvement in the recognition process.

The point of this postcolonial critique is not to dismiss the overwhelmingly positive incursions into the dominant legal discourse brought about by the Reports, but simply to expose some of the inherent limitations of the exercise when the Other continues to be subsumable. Indeed, given that the Indigenous Other in this country is rarely provided with the opportunity to speak, it would be unhelpful to turn the other way when this chance is finally accorded. Thus, the aim is not to criticise negatively the approach adopted by the Law Reform bodies, but rather, to use a postcolonial framework in order to gain a more nuanced understanding of who is setting the parameters of the inquiry, what is being recognised as 'customary' (and why), and what will ultimately be recognised as 'law' (and by whom).

Finally, from a postcolonial standpoint, the Reports essentially provide an opportunity to exploit the hybrid 'in-between' space created by the colonial process in Australia - where, as Bhabha would put it, the former colonisers are also forced to re-define themselves in relation to their Other. In this way, both the Other and its West are forced into a different dialectic, with new possibilities of slightly fuller realities being recognised. And to the extent that this process will inevitably contest law's innocent (but grandiose) claims to universality, this can only be a good thing.

\section{CONCLUSION}

While legal scholars have been rather tentative in their engagement with postcolonial discourse, this is now slowly (and finally) changing. It is submitted that the likelihood of legal scholars (and indeed, other scholars) engaging in postcolonial theory will increase when there is a greater acknowledgement that '[a]ll post-colonial societies are still subject in one way or another to overt or subtle forms of neo-colonial domination, and independence has not solved this 
problem. ${ }^{201}$ Indeed, to dismiss postcolonial theory as anachronistic, or unduly focused on a bygone era, is both simplistic and dangerous. ${ }^{202}$

Although on some levels postcolonial discourse threatens to become the last bastion for continuing the colonial dichotomies of the West and its Other, and for further institutionalising the antagonistic struggles over a thoroughly disciplined terrain, debates at the heart of contemporary postcolonial theory are essentially concerned with the reterritorialisation of the non-Western world. Indeed, a key concern for postcolonial theory is to identify new forms of harm and domination, and trace the contemporary condition of subjugation of the historically Othered. In the words of Fitzpatrick and Darian-Smith, postcolonialism today maintains 'an intense engagement with many matters of current intellectual significance - with questions of alterity and identity, with community and globalism, with racism's now protean forms, and, in a way above all, with the centrality of law to all this. ${ }^{, 203}$ Indeed, the law remains an integral component of the colonial, imperial, and now postcolonial projects.

Ultimately, using postcolonial theory in legal discourse may simply be viewed as an act of criticism, a disapproval, an interpellation, a gentle reminder, as the law has taken for granted some primary categories and presumptions, the foundations of which are unquestioned and, indeed, which have the status of eternal truths. Postcolonial theory's interrogatory style may be used to illustrate that categories we consider as 'natural' have actually been culturally constructed in hierarchical structures of difference. A postcolonial reading of law also compels us to explore the role played by legal discourse in continuing the colonial narrative of dominance and subordination in this apparently postcolonial age. Moreover, postcolonial theory offers legal discourse some critical tools about method, particularly a wariness toward generalisations which transcend the boundaries of culture and region. Perhaps, above all, postcolonial theory may be used in legal discourse as a platform to challenge the nature of law's imperialism, and the base from which it unquestioningly operates.

Ashcroft, Griffiths and Tiffin, The Post-Colonial Studies Reader, above n 9, 2.

It should be noted that some scholars have been critical of postcolonial theory's interest in the colonial era. For example, Arif Dirlik suggests that postcolonial studies should focus more directly on contemporary neocolonial global imbalances, rather than be excessively captivated with the historical past. According to Dirlik, '[p]ostcolonial critics have engaged in valid criticism of past forms of ideological hegemony but have had little to say about its contemporary figurations': See Arif Dirlik, 'The Postcolonial Aura: Third World Criticism in the Age of Global Capitalism' in Mongia (ed) Contemporary Postcolonial Theory: a Reader (1996) 294-320, 315. Ania Loomba also suggests that postcolonial studies must 'absorb itself far more deeply with the contemporary world' if it 'is to survive in any meaningful way': See Loomba, above n 121, 256. 